\section{Ankara Üniversitesi Eğitim Bilimleri Fakültesi Özel Eğitim Dergisi}

2022, 23(2), 271-294

\section{ARAŞTIRMA}

Gönderim Tarihi: 25.05.20

Kabul Tarihi: 17.06.21

Erken Görünüm: 11.07.21

\title{
Özel Yetenekli Öğrencilerin Psikolojik Sağlamlığının Yordayıcıları: Benlik Saygısı, Akran İlişkileri ve Ebeveyn Tutumları*
}

\author{
İrem Yörük-Topuz 1
}

\author{
Zeynep Cihangir-Çankaya ${ }^{2}$
}

\begin{abstract}
$\ddot{O} z$
Giriş: Bu araştırma, özel yetenekli öğrencilerin psikolojik sağlamlık düzeylerinde benlik saygısının, anne baba tutumlarının ve akran ilişkilerinin rolünü incelemek amacıyla yapılmıştır. Araştırmanın amacı doğrultusunda araştırmada "özel yetenekli öğrencilerin benlik saygısı, ebeveyn tutumları ve akran ilişkilerinden aldıkları puanların psikolojik sağlamlık düzeylerini yordama gücü nedir?” sorusuna yanıt aranmıştır.

Yöntem: Araştırmada ilişkisel tarama modeli kullanılmıştır. Çalışma grubu, üç ayrı Bilim ve Sanat Merkezi’ne devam eden, toplam 219 öğrenciden (6., 7., 8., 9. sınıf ve lise hazırlık sınıfı öğrencisi) oluşmuştur. Araştırma verileri Ergen Psikolojik Dayanıklılık Ölçeği, Rosenberg Benlik Saygısı Ölçeği Kısa Formu, Anne-Baba Tutum Ölçeği ve Akran İlişkileri Ölçeği ile toplanmıştır. Ölçeklerden elde edilen veriler çoklu regresyon analizi ile çözümlenmiştir.

Bulgular: Araştırma sonuçları anne babadan alınan kabul/ilginin ve psikolojik özerklik desteğinin, benlik saygısı ve akran ilişkileri değişkenlerinin, özel yetenekli öğrencilerin psikolojik sağlamlık düzeylerini anlamlı bir şekilde yordadığını, anne babanın kontrol/denetleme davranışlarının ise anlamlı bir şekilde yordamadığını ortaya koymuştur. Anne babadan alınan kabul/ilginin, özel yetenekli öğrencilerin psikolojik sağlamlığının en güçlü yordayıcısı olduğu görülmüştür.

Tartışma: Araştırmadan elde edilen bulgular, benlik saygısının, aile ve arkadaş ilişkilerinin özel yetenekli öğrencilerin psikolojik sağlamlıklarının açıklanmasında önemli bir güce sahip olduğunu göstermektedir. Bununla birlikte araştırma sonuçları, özel yetenekli öğrencilerin psikolojik sağlamlık düzeylerini, anne babadan alınan kabul/ilgi ve akran ilişkileri gibi dışsal koruyucu faktörlerin daha güçlü bir biçimde açıkladığını ortaya koymuştur. Ayrıca içsel bir koruyucu faktör olan benlik saygısının da özel yetenekli öğrencilerin psikolojik sağlamlı̆̆ını anlamlı bir biçimde yordadığı görülmektedir.
\end{abstract}

Anahtar sözcükler: Özel yetenekli öğrenciler, psikolojik sağlamlık, benlik saygısı, anne baba tutumları, akran ilişkileri.

Atıf için: Yörük-Topuz, İ., \& Cihangir-Çankaya, Z. (2022). Özel yetenekli öğrencilerin psikolojik sağlamlığının yordayıcıları: Benlik saygısı, akran ilişkileri ve ebeveyn tutumları. Ankara Üniversitesi Eğitim Bilimleri Fakültesi Özel Eğitim Dergisi, 23(2), 271-294. https://doi.org/10.21565/ozelegitimdergisi.742426

\footnotetext{
*Bu araştırma, 'Özel Yetenekli Öğrencilerin Psikolojik Sağlamlık Düzeylerinin Benlik Saygısı, Akran İlişkileri ve Ebeveyn Tutumları Açısından İncelenmesi’ başlı̆̆ını taşıyan yüksek lisans tez çalışmasının (2019) özeti niteliğindedir. ${ }^{1}$ Uzm. Psk. Danışman, Erdek Karşıyaka Ortaokulu, E-posta: iremyoruk35@gmail.com, https://orcid.org/0000-0003-38834783

${ }^{2}$ Sorumlu Yazar: Doç. Dr., Ege Üniversitesi, E-posta: zeynep.cankaya.cinhangir@ege.edu.tr, https://orcid.org/0000-00017120-931X
} 


\section{Giriş}

Son yıllarda insanın gelişimini desteklemek için, geleneksel psikolojinin zayıf yanlara, eksikliğe ve patolojiye yönelik vurgusundan ziyade, güçlü yanlara ve pozitif duygulara odaklanılmasının gerekli olduğu belirtilmektedir (Seligman \& Csikszentmihalyi, 2000). Pozitif psikoloji akımı olarak adlandırılan bu bakış açısı, bireylerin zayıf yönlerini düzeltmekten çok olumlu niteliklerini geliştirmeye imkân sağlamaktadır. Geleneksel psikoloji anlayışından farklı bir tema üzerine şekillenen pozitif psikoloji, bozuk olanı onarma ve hastalıkların iyileşmesinin yanı sıra, en iyiyi inşa etmeyle ve sağlıklı insanların yaşamlarının nasıl daha doyurucu hale geleceğiyle de ilgilenmektedir (Bişgin, 2013). Bu akımın temel aldığ 1 varsayım çevrenin; bireylerin iyimserlik, psikolojik sağlamlık, yeterlik gibi güçlü yönlerini geliştireceği yönündedir (Clonan vd., 2004).

Bireyin pozitif özelliklerinden birisi olan psikolojik sağlamlık, yaşamda karşılaşılan stres, risk ve sıkıntılara rağmen hayatlarına başarılı bir şekilde devam eden bireylerle devam edemeyenler arasındaki temel bir farklılıktır (Zakeri vd., 2010). Psikolojik sağlamlık teorisinin merkezinde, bireyin eksiklikleri yerine güçlü yönleri yer almaktadır (Kaul vd., 2015). Kavramın operasyonel tanımı konusunda fikir birliği olmamakla birlikte temel soru, bazı bireylerin fiziksel veya zihinsel sağlık sorunları geliştirmeden sıkıntıya nasıl dayandığı (Herrman vd., 2011) ve acı veren travmatik deneyimlere rağmen olumlu sonuçların ne zaman ve ne şekilde ortaya çıkabildiğidir (Wener, 2016). Psikolojik sağlamlık, bireylerin maruz kaldıkları zorluklara ve potansiyel travmatik durumlara karşı psikolojik uyumu ifade eden psikososyal ve gelişimsel bir süreçtir (Graber vd., 2015). Reis ve diğerleri (2004), psikolojik sağlamlığın belirli kişisel, çevresel ve sosyal faktörlerin birleşiminden kaynaklandığını belirtmektedir. Psikolojik sağlamlık tanımlarında yer alan ortak özellikler risk faktörleri, olumsuz etkiyi azaltan koruyucu faktörler ve uyumdur (Fraser vd., 1999; Gizir, 2007; Işık, 2016). Risk faktörleri, uyumsuzluk olasılı̆̆ını artıran; koruyucu veya teşvik edici faktörler ise, uyumu geliştiren özellikleri içermektedir (Lee vd., 2013). Birey riskler, stresli yaşam olayları ve koruyucu faktörler arasında denge sağlayabildiği sürece yaşamla başa çıkabilmektedir. Ancak risk faktörleri ve stresli yaşam olayları koruyucu faktörlerden daha ağır basarsa, psikolojik sağlamlığı yüksek olan birey bile sorun yaşayabilmektedir (Werner, 1989). Koruyucu faktörler ve risk faktörleri aynı kategorilere sahiptir. Koruyucu faktörler bireysel özellikleri, aile ve aile dışındaki sosyal çevreyle ilgili faktörleri içeriyorken; risk faktörleri de bu şekilde sınıflandırılmaktadır (Balcı, 2018; Önder \& Gülay, 2008).

Düşük IQ bir risk faktörü olarak ele alınmakla birlikte (Dole, 2000) yüksek IQ ya da özel yeteneğe sahip olmak her zaman koruyucu bir faktör olmamaktadır. Psikolojik sağlamlık araştırmalarında en çok incelenen ara değişkenlerden biri olan zihinsel yeteneğin hem koruyucu etkiler gösterdiğini hem de incinebilirlik faktörü olarak ele alınabileceğini gösteren araştırmalar bulunmaktadır (Luthar \& Zigler, 1991; Pollet \& Schnell, 2017; Renati vd., 2017; Vötter, 2019). Luthar (1991), düşük stres seviyelerinde zekânın yeterlik ile pozitif ilişkili olduğunu; stres seviyeleri yüksek olduğunda ise zeki çocukların avantajlarını yitirdiklerini, yeterlik düzeylerinin kendilerinden daha düşük bilişsel potansiyele sahip çocuklarla benzer olduğunu belirtmiştir. Çocuklar stres yaşadığında, zekânın koruyucu olmaktan ziyade savunmasızlık mekanizması olarak işlev gösterdiğini ortaya koymuştur. Başka bir ifade ile özel yeteneklilik, çocukların gelişimlerini bazı psikolojik sıkıntılar yaşamalarına yol açacak biçimde etkileyebilmektedir (Renati vd., 2017). Yüksek IQ ve yüksek zihinsel fonksiyonun, psikolojik olarak sağlam bireylerin bir özelliği olarak görüldüğü ve psikolojik sağlamlıkta koruyucu bir faktör olarak ele alındığı çalışmalar da bulunmaktadır (Fergusson \& Lynskey, 1996; Gizir, 2007; Gürgan, 2006; Karaırmak, 2006; Masten \& Coatsworth, 1998). Ancak özel yetenekli bireylerin, eş zamanlı olmayan gelişimleri, özel yetenekli etiketinin altında kalmaları, ailelerinin ve çevrelerinin onlardan beklentileri, eğitim ortamlarından doyum sağlayamayabilmeleri, onları dezavantajlı konuma getirmekte ve özel yetenekli çocuklar için risk faktörü oluşturmaktadır (Pfeiffer \& Stocking, 2000). Bunların yanında özel yetenekli çocukların, onları sosyal ve duygusal sorunlara karşı savunmasız bırakabilen kişilik özelliklerine sahip olabildikleri (Pfeiffer \& Stocking, 2000); özel yetenekli oldukları için sosyal duygusal zorluklar yaşayabildikleri belirtilmektedir (Altman, 1983; Buescher, 1985; Freeman, 1983; Gallagher, 1990; Roedell, 1984). Saranlı (2017), üstün yetenekli çocukların gelişimsel açıdan tüm alanlarda üstün olduklarının yaygın bir önyargı olarak karşımıza çıktığını belirterek; eş zamanlı olmayan gelişim sonucunda üstün yetenekli bir çocuğun bazı gelişim alanlarında yaşıtlarından üstün, bazılarında ortalama düzeyde, bazılarında ise yaşıtlarından geride olabileceğini ifade etmektedir.

Benzer biçimde akademik olarak özel yetenekli öğrencilerin sosyal ve duygusal uyumlarının, ruh sağlıklarının ve psikolojik iyilik hallerinin her zaman yeterli olduğunu varsaymamak gerektiği, bu çocukların farklı oldukları ve sosyal duygusal gelişimlerinin desteklenmesinin önemli olduğu ileri sürülmüştür (Dixon vd., 2001). Sosyal duygusal gelişimleri kapsamında, duygusal derinliğe sahip olma, duyguları yoğun olarak yaşama, yoğun duygusal tepkiler verme ve aşırı duyarlılık özelliklerine pek çok üstün yetenekli çocuğun sahip olduğu ifade edilmektedir (Saranlı, 2017). Bu bağlamda özel yetenekli çocuklar için yetenekliliğin "psikolojik sağlamlığı 
artırdığı” ve "savunmasızlığı artırdığı” şeklinde iki farklı görüş bulunmaktadır (Neihart \& Yeo, 2018). Özel yetenekli öğrencilerin duygusal gelişimine dikkat çeken Sternberg ve diğerleri (2001), IQ'nun okul başarısındaki varyansın yalnızca yaklaşık \%25'ini ve iş performansındaki varyansın \%4 ila \%30'unu oluşturduğunu ifade etmiştir. Bu çerçevede özel yetenekli öğrencilerin psikolojik sağlamlık düzeylerinin düşük olmasının, okulda karşılaştıkları zorluklarla başa çıkmalarını olumsuz etkilediği de fark edilmeye başlanmıştır. Bu farkındalık artan sayıda araştırma yapılmasını sağlamıştır (Alexopoulou vd., 2019). Özel yetenekli olmanın avantaj ve dezavantaj olarak görüldüğü her iki öğrenci grubuyla da çalışan King (2009), özel yetenekli olmanın avantaj olarak görüldüğü gruptaki öğrencilerin akademik, sosyal, sanatsal alanlarda başarılı olduklarını ve genellikle doyum sağlayıcı bir kariyerlerinin olduğunu; dezavantaj olarak algılanan gruptaki öğrencilerin ise uyum sağlayamadıklarını, zorbalığga maruz kaldıklarını, akademik ortamda sıkıldıklarını, hayal kırıklığına uğradıklarını ve sınıf ortamında davranış problemleri sergileyebildiklerini ifade etmiştir. Akademik olarak özel yetenekli öğrencilerin de çok zeki ve akademik olarak rekabetçi olmalarına rağmen, kendilerine acı veren ve güçsüzleştiren psikolojik problemler yaşayabildikleri belirtilmektedir (Pfeiffer \& Stocking, 2000). Bu durum Saranlı (2017) tarafindan yapılan çalışmada da vurgulandığı üzere özel yetenekli çocukların sosyal duygusal gelişim alanında güçlük yaşamasına yol açmaktadır. Özel yetenekli ergenlerin kendilerine özgü bu duygusal zorluklarının yanında, duygusal ve davranışsal problemler açısından tüm ergenlerle benzer risklerle karşı karşıya olduğu ifade edilmiştir (Chen vd., 2017).

Saranlı ve Metin (2012) tarafından yapılan derleme çalışmasında belirtilen, özel yetenekli çocukların yaşayabilecekleri mükemmeliyetçilik, stres, yalnızlık, depresyon gibi sosyal duygusal problemlerle başetmelerinde yardımcı olacak özelliğin psikolojik sağlamlık olduğu düşünülmektedir. Özel yetenekli çocukların hem arkadaşlarıyla dengeli bir ilişki yürüterek, arkadaşlık ihtiyaçlarını karşılamaları hem de kendi uzmanlık alanlarında gösterecekleri çaba arasında denge kurabilmeleri için de psikolojik sağlamlıklarının yüksek olması gerektiği ifade edilmektedir (Zulfikar vd., 2020). Bu çocuklar yetişkin olduklarında onları risklere karşı koruyacak özelliklerinin psikolojik sağlamlık kapasiteleri olduğu vurgulanmıştır (Alexopoulou vd., 2019). Reis ve diğerleri (2004) psikolojik sağlamlığın, başarılı olan ve başarılı olamayan özel yetenekli öğrenciler arasında ayırım yapabilecek önemli bir özellik olduğunu ortaya koymuşlardır. Benzer şekilde, özellikle özel yetenekli ama düşük başarıya sahip çocukların akademik sağlamlıklarının yükseltilmesine ihtiyaç olduğu ifade edilmiştir (Zulfikar vd., 2020).

Neihart (1999) çalışmasında özel yetenekli bireylerin psikolojik sağlık ve uyumlarının yüksek IQ düzeyleriyle değil, mizaç, kişilik, alınan eğitimin niteliği ve yaşam koşulları değişkenleriyle ilişkili olduğunu ortaya koymuştur. Benzer şekilde Kitano ve Lewis (2005), zekânın, psikolojik sağlamlığın tek koşulu olmadığını ancak problem çözme ve karar verme becerilerin de destekleyici bir rol oynadığını ifade etmiştir. Psikolojik sağlamlığı yüksek olan özel yetenekli bireylerin, içsel motivasyonlarının yüksek olduğu, öğrenme sürecinde etkili stratejiler kullandıkları (Zhang \& Sternberg, 2000), sorun çözme, mantıksal ve eleştirel düşünme yeteneklerinin, etik duyarlılıklarının, ders dışı ilgi alanlarının, başarılardan duydukları memnuniyetin de onların psikolojik sağlamlığını artırdığı görülmüştür (Neihart, 2002).

Bu açılardan özel yetenekli öğrencilerin psikolojik sağlamlıkları ile ilişkili araştırmalar yapmak ve onların psikolojik sağlamlıklarını yükseltecek çalışmalar planlamak anlamlı görülmektedir. İlgili alanyazında çocuk ve ergenlerle yürütülen psikolojik sağlamlık çalışmaları incelendiğinde, dezavantajlı bireylere yönelik araştırma sayısının (ör. Bumpus, 2014; Eminağaoğlu, 2006; Er, 2009; Kidd \& Shahar, 2008) özel yetenekli bireylerle yürütülen çalışmalara (ör. Chen vd., 2017; King, 2009; Kline \& Short, 1991) oranla daha fazla olduğu görülmektedir. Ülkemizde ise, özel yetenekli öğrencilerde benlik saygısı (Albayrak-Dengiz, 2014; Altun \& Yazıc1, 2012; Büyüktaşkapu-Soydan \& Kabar, 2020; Olgun-Kaval, 2014), ebeveyn tutumları (Afat, 2013), akran ilişkileri (Erol, 2015; Oğurlu, 2010; Özbey vd., 2021), duygusal zeka (Koçak \& İçmenoğlu, 2012), iletişim becerileri (Koç, 2015), sosyal duygusal sorunlar (Saranlı \& Metin, 2012) değişkenleri araştırmalarda ele alınmış olsa da, özel yetenekli öğrencilerin psikolojik sağlamlığına yönelik yapılmış bir araştırmaya rastlanmış (Uçak-Azboy, 2020), bir araştırmada da özel yetenekli bireylerin ailelerinde psikolojik sağlamlığın incelendiği görülmüştür (Kahvecioğlu, 2016).

Psikolojik sağlamlıkta benlik saygısı, akran ilişkileri ve anne baba tutumları koruyucu faktörler olarak ele alınmaktadır. Özel yetenekli öğrencilerin benlik saygısına yönelik ülkemizde yapılmış çalışmalarda, özel yetenekli öğrencilerin olumlu benlik algısına sahip oldukları (Büyüktaşkapu-Soydan \& Kabar, 2020; Metin \& BencikKangal, 2012), benlik algılarının ve öz yeterlik düzeylerinin fen lisesinde öğrenim gören (Altun \& Yazıc1, 2012) ve normal gelişim gösteren akranlarına (Yürük, 2003) göre daha olumlu olduğu, benzer biçimde özel eğitim almayan üstün yetenekli öğrencilerin benlik algılarının da, özel eğitim alan öğrencilerden daha olumlu olduğu 
görülmüştür (Bildiren, 2018). Belirtilen araştırmalarda özel yetenekli olmanın öğrencilerin benlik algıları üzerinde olumlu etkileri olduğu değerlendirilmesinde bulunulmuştur.

Özel yetenekli öğrencilerin akran ilişkilerine yönelik yapılan çalışmalarda, daha çok kendi özelliklerine (zeka, ilgi alanları vb.) benzer özelliklere sahip arkadaşlar seçtikleri (Alkan, 2013); arkadaşlarına dair olumlu düşüncelere sahip oldukları (Büyüktaşkapu-Soydan \& Kabar, 2020); yeni arkadaşlar edinmekten keyif aldıkları, arkadaşları tarafından anlaşıldıklarını hissettikleri (Koç, 2015); arkadaşlık ilişkilerinde kendilerini yeterli ve iyi gördükleri, arkadaşlarıyla vakit geçirmekten mutlu oldukları, arkadaşları tarafından sevildiklerini düşündükleri (Özbey vd., 2021), akranlarından daha başarılı olmalarını sağlayan özelliklerinin onların akran gruplarından dışlanmalarına ve yalnız kalmalarına neden olabileceği (Helt, 2008; Karakuş, 2010) ortaya konulmuştur. Görüldüğü gibi, özel yetenekli öğrencilerin arkadaş ilişkilerinde zorlandıklarını ve ilişkilerden doyum aldıklarını gösteren çalışmalar bulunmaktadır. Özel yetenekli öğrencilerin aile ilişkileriyle ilgili yapılan çalışmalarda, aileleri tarafından anlaşıldıklarını ve önemsendiklerini hissettikleri (Koç, 2015), aileleri tarafından değerli görüldüklerine ve sağlıklı bir aile yapısı içinde bulunduklarına inandıkları (Karatay, 2018) görülmüştür. Tohum (2018) tarafından yapılan çalışmada, öğrencilerin mutluluk kaynağı olarak aileyi ön planda tuttuğu bulunmuştur.

Bu araştırmada, özel yetenekli öğrencilerin, özel yetenekli olmalarından kaynaklı bireysel ve çevresel zorluklar sebebiyle risk altında olabilecekleri görüşü doğrultusunda, psikolojik sağlamlıklarının artırılmasında içsel ve dışsal koruyucu faktörlerin etkisine ilişkin boşluk doldurulmaya çalışılmıştır. Lee ve diğerleri (2013), psikolojik sağlamlığı arttırmak için koruyucu faktörlerin (ör. öz yeterlik, olumlu etki ve öz saygı) arttırılmasının, risk faktörlerini (ör. depresyon ve anksiyete) azaltmaktan daha etkili olduğunu belirtmektedir. Kim (2015) de özel yetenekli öğrencilerin psikolojik sağlamlığının gelişimini etkileyen faktörleri, öğrencilerin kişisel özellikleri, aile ortamı ve daha geniş sosyal çevre olarak ele almıştır. Bu nedenlerle bu araştırmada içsel koruyucu faktör olarak benlik saygısı, dışsal koruyucu faktörler olarak anne-baba tutumları ve akran ilişskileri incelenmiştir. Bu bağlamda araştırmanın amacı, özel yetenekli öğrencilerin psikolojik sağlamlıklarının yordayıcısı olarak benlik saygısı, annebaba tutumları ve akran ilişkilerinin rolünü incelemektir. Araştırmanın amacı doğrultusunda araştırmada "Özel yetenekli öğrencilerin benlik saygısı, ebeveyn tutumları ve akran ilişkilerinden aldıkları puanların psikolojik sağlamlık düzeylerini yordama gücü nedir?" sorusuna yanıt aranmıştır. Araştırma bulgularının özel yetenekli öğrencilerin psikolojik sağlamlığını artırmada etkili olan koruyucu faktörlerin etkisini ortaya koyarak özel yetenekli çocuklarda psikolojik sağlamlığın nasıl arttırılabileceğine ilişkin, özel yetenekli öğrencilerle çalışan psikolojik danışmanlara ve öğretmenlere, öğrencilerin ebeveynlerine 1şık tutacağ düşünülmektedir.

\section{Yöntem}

\section{Araştırma Deseni}

$\mathrm{Bu}$ araştırma özel yetenekli öğrencilerin psikolojik sağlamlık düzeylerinin benlik saygısı, akran ilişkileri ve ebeveyn tutumları değişkenleri tarafından yordama gücünü ortaya koymak amacıyla yapılmış ilişkisel tarama modeline dayalı betimsel bir araştırmadır. Tarama modelleri geçmişte ya da hala var olan bir durumu var olduğu şekliyle betimlemeyi amaçlayan araştırma yaklaşımıdır. İlişkisel tarama modelleri ise iki ya da daha çok değişken arasındaki birlikte değişimin varlığını ve/veya derecesini belirlemeyi amaçlayan araştırma modelidir (Karasar, 2014).

\section{Katılımcilar}

Araştırmanın katılımcılarını 2018-2019 eğitim-öğretim yılında Türkiye'nin batısındaki bir ilde bulunan üç ayrı Bilim ve Sanat Merkezinde öğrenim gören, 6., 7., 8. ve 9. sınıfta ve hazırlık sınıfında öğrenim gören 252 özel yetenekli öğrenci oluşturmuştur. Bilim ve Sanat Merkezine devam eden ve çalışmaya katılmaya gönüllü tüm öğrenciler araştırmaya dâhil edilmiştir. Öğrenciler tarafından hatalı veya eksik doldurulan 9 adet veri toplama aracı değerlendirme dışı bırakıldıktan sonra kalan 243 veri üzerinde uç değer analizleri yapılmıştır. Tek değişkenli ve çok değişkenli toplam 24 verinin çıkarılmasının ardından son haliyle 219 özel yetenekli (genel zihinsel yetenek) öğrenciden oluşan bir çalışma grubu elde edilmiştir. Çalışma grubunda yer alan öğrencilerin 125'i (\%57) erkek, 94'ü (\%43) kız öğrencidir. Çalışmaya katılan öğrencilerin yaşları 11 ile 15 arasında değişmektedir. Öğrencilerin yaş ortalaması 13.5'tir. Toplamda 45 öğrenci 6. sınıf, 59 öğrenci 7. sınıf, 69 öğrenci 8. sınıf, 15 öğrenci lise hazırlık sınıfı, 31 öğrenci 9. sınıftır. Araştırmada özel bir grupla çalışıldığı ve ilgili kurumlardan araştırma izni alma güçlüğü nedeniyle kolay ulaşılabilir örnekleme yöntemi kullanılmıştır. Bu yöntemde çalışma için uygun olan belirli bir grup insan seçilmektedir. Başka bir örnekleme yönteminin kullanılmasının zor olduğu durumlarda bu yöntem tercih edilmektedir (Fraenkel \& Wallen, 2009). 


\section{Veri Toplama Araçları}

Çalıșmanın verileri dört ölçme aracı ile toplanmıștır. Bu veri toplama araçları Ergen Psikolojik Dayanıklılık Ölçeği, Rosenberg Benlik Saygısı Ölçeği-Kısa Formu, Anne-Baba Tutum Ölçeği ve Akran İlişkileri Ölçeği' dir. Veri toplama araçlarına ait detaylı bilgiler aşağıda verilmiştir.

\section{Ergen Psikolojik Dayanıklılık Ölçeği}

Bulut ve diğerleri (2013) tarafından geliştirilen ölçek, 29 maddeden ve aile desteği, akran desteği, okul desteği, uyum, mücadele azmi ve empati olmak üzere 6 boyuttan oluşmaktadır. Ölçekten alınabilecek puanlar 29 ile 116 arasında değişmekte ve puanların yükselmesi, kişinin psikolojik sağlamlık düzeyinin yüksekliğine işaret etmektedir. Ölçeğin ergen grup üzerinde yapılan geçerlik çalışmaları kapsamında yapılan açımlayıcı faktör analizi sonucunda, 6 faktörlü yapının toplam varyansın \%56.99’unu açıkladığ1 görülmüştür. Ölçeğin ölçüt geçerliği kapsamında problem çözme envanterinden alınan puanlarla Ergen Psikolojik Dayanıklılık Ölçeği puanları arasında -.47 $(p<.001)$, Ergen Psikolojik Dayanıklılık Ölçeği ile Kontrol Odağ Ölçeği arasında $-.46(p<.001)$ ve Ergen Psikolojik Dayanıklılık Ölçeği ile Beck Umutsuzluk Ölçeğinden alınan puanlarla -.61 $(p<.001)$ ilişki bulunmuştur. Ölçeğin güvenirlik çalışmaları kapsamında, test-tekrar test güvenirliği .87, ölçeğin tamamı için Cronbach Alfa güvenirliği .87, \%27'lik alt ve üst grubun t-testi sonuçlarına göre, alt ve üst grup arasında anlamlı $(p<.005)$ bir farkın olduğu bulunmuştur (Bulut vd., 2013). Bu araştırmada ölçeğin güvenirlik analizi yenilenmiş ve Cronbach Alfa iç tutarlılık katsayısı .86 bulunmuştur.

\section{Rosenberg Benlik Saygısı Ölçeği-Kısa Formu}

Rosenberg tarafından geliştirilen ölçek, 63 madde 12 alt kategoriden oluşmaktadır. Bu çalışmada benlik saygısını ölçen, 10 maddeden oluşan benlik saygısı alt kategorisi kullanılmıştır. Benlik saygısı alt ölçeği, Guttman değerlendirme yöntemiyle, ilk üç soru kendi aralarında, dördüncü ve beşinci sorular kendi aralarında, dokuzuncu ve onuncu sorular kendi aralarında puanlanmaktadır. Altıncı, yedinci ve sekizinci maddeler ise her biri kendi puanlanır. Ölçekten alınabilecek en yüksek puan 6'dır. 0-1 puan yüksek, 2-4 puan orta ve 5-6 puan düşük benlik saygısı düzeyini ifade etmektedir. Rosenberg Benlik Saygısı Ölçeği'nin Türkiye'deki geçerlik ve güvenirlik çalışmaları Çuhadaroğlu (1986) tarafından yapılmıştır. Ölçeğin benlik saygısı alt kategorisinin geçerliği için psikiyatrik görüşmeler yapılmıştır. Yapılan görüşmeler ve Benlik Saygısı alt ölçeğinden elde edilen sonuçlar arasındaki ilişki hesaplanmış ve geçerlik katsayısı .71, güvenirlik katsayısı .75 olarak bulunmuştur. Başka bir çalışmada benlik saygısı alt ölçeğinin iç tutarlılık katsayısı .82 olarak hesaplanmıştır (Çeçen, 2008). Bu araştırmada ölçeğin güvenirlik analizi yenilenmiş ve Cronbach Alfa iç tutarlılık katsayısı .71 bulunmuştur.

\section{Anne-Baba Tutum Ölçeği}

Lamborn ve diğerleri (1991) tarafından geliştirilen ölçek, 26 maddeden ve kabul-ilgi, kontrol-denetleme ve psikolojik-özerklik olmak üzere üç faktörden oluşmaktadır (Yılmaz, 2000). Anne-Baba Tutum Ölçeği'nin Türkçe uyarlama çalışması Yılmaz (2000) tarafından ilköğretim, lise ve üniversite öğrencileri üzerinde yapılmıştır. Ölçekten alınabilecek en düşük ve en yüksek puan kabul ilgi boyutu için 9-36; psikolojik özerklik boyutu için 728; denetleme boyutu için 5-23'dür. Ölçeğin geçerlik çalışmasında, ölçüt bağlantılı geçerliğe kanıt olarak, akademik başarı puanları ile anne-babalarının demokratiklik düzeyleri arasında ilköğretim $(F=6.69, s d=3$ ve $116 ; p<.001)$ ve lise $(F=4.28, s d=3$ ve $116 ; p<.01)$ öğrencileri için anlamlı farklılıklar bulunmuştur. İlköğretim dönemindeki öğrencileri için test tekrar test ve iç tutarlılık (Cronbach Alfa) katsayıları sırasıyla, kabul-ilgi alt ölçeği için .74 ve .60, kontrol-denetleme alt ölçeği için .93 ve .75, psikolojik-özerklik alt ölçeği için .79 ve .67 olarak bulunmuştur (Yılmaz, 2000). Bu araştırmada ölçeğin güvenirlik analizi yenilenmiş ve Cronbach Alfa iç tutarlılık katsayıları kabul/ilgi alt ölçeği için .67, denetleme alt ölçeği için .57, psikolojik özerklik alt ölçeği için .73 olarak bulunmuştur. Cronbach Alfa değerinin .60 ve üzeri kabul edilebilir olduğu ifade eden kaynaklar bulunmaktadır (Taber, 2018; Van-Griethuijsen vd., 2014). Ayrıca ölçeğin madde sayısının az olmasının Alfa değerini etkilediği bilinmektedir (Nunnally \& Bernstein, 1994). Denetleme alt ölçeğinde altı maddenin yer almasının böyle bir sonuca neden olduğu düşünülmektedir. Denetleme alt ölçeğinin madde toplam korelasyonlarının .27 ile .51 arasında değiştiği görülmüştür. Madde sayısının azlığı ve madde toplam korelasyonları göz önüne alındığında .57 kabul edilebilir olarak değerlendirilebilir.

\section{Akran İlişkileri Ölçeği}

Bukowski ve diğerleri (1994) tarafından geliştirilen ölçeğin uyarlama çalışmaları Erkan-Atik ve diğerleri (2014) tarafından yapılmıştır. Ölçekten 22 maddeden ve birliktelik, çatışma, yardım, koruma ve yakınlık olmak üzere beş alt boyuttan oluşmaktadır. Ölçekten alınabilecek en düşük puan 22, en yüksek puan 110'dur. Ölçeğin 
Türkçe formunda yer alan maddelere ilişkin faktör yük değerleri .37 ile .81 arasında değişmektedir. Ölçeğin beş faktörlü yapısı Doğrulayıcı Faktör Analizi sonucunda belirlenen beş faktörlü akran ilişkileri modelinin $\left(\chi^{2} s B / s d=\right.$ $669.12 / 199, p=.00, \mathrm{RMSEA}=.063, \mathrm{CFI}=.97, \mathrm{GFI}=.88, \mathrm{NNFI}=.96)$ iyi uyum değerlerine sahip olduğu görülmüştür. Ölçeğin Türkçe formunun Cronbach Alfa katsayıları .66 ile .86 arasında değişmektedir (Erkan-Atik vd., 2014). Bu araştırmada ölçeğin güvenirlik analizi yenilenmiş ve Cronbach Alfa iç tutarlılık katsayısı .85 bulunmuştur.

\section{Verilerin Toplanması}

Araştırmada verilerin toplanması aşamasında, ilk olarak Ege Üniversitesi Sosyal ve Beşeri Bilimler Araştırma ve Yayın Etiği Kurulundan 01/11/2018 tarih ve 85553214-050.06.04 sayı numaralı onay alınmıştır. Araş̧ırma verileri 2018-2019 eğitim öğretim yılı Aralık ve Ocak olmak üzere yaklaşık 2 aylık sürede toplanmıştır. Uygulamaya başlamadan önce uygulamanın yapılacağı kurumlardaki okul yönetimi ve psikolojik danışmanlara araştırmanın amacı ve önemi anlatılmış, uygulamanın yapılacağı tarihler ve saatler planlanmıştır. Veri toplama araçları araştırmacılardan birisi, psikolojik danışmanlar ve ders öğretmenleri tarafından uygulanmıştır. Uygulama öncesinde öğrencilere araştırma hakkında genel bilgi verilmiştir. Cevapların gizli tutulacağı, öğretmenleri ve ebeveynleri ile paylaşılmayacağı, sorulara içten ve samimi bir şekilde yanıt vermelerinin onların yaşamları hakkında daha doğru bilgilere ulaşılması açısından önemli olduğu vurgulanmıştır. Hazırlanan ölçek bataryası yaklaşık olarak 20 dakika içerisinde uygulanmıştır.

\section{Verilerin Analizi}

Benlik saygısı, anne-baba tutumları ve akran ilişkilerinin, özel yetenekli öğrencilerin psikolojik sağlamlık düzeylerini yordama gücünü belirlemek amacıyla aşamalı çoklu regresyon analiz yöntemi kullanılmıştır. Araştırmadan elde edilen veriler SPSS 23 paket programı kullanılarak analiz edilmiştir. Çoklu regresyon analizi öncesinde, veri seti üzerinde uç değerler, normallik ve çoklu birlikte değişim varsayımları test edilmiştir. Tek değişkenli uç değerler için $\mathrm{Z}$ değerleri incelenmiştir. Çok değişkenli uç değerler ise Mahalanobis uzaklık testiyle incelenmiştir. Mahalonobis uzaklık değerleri için .001 anlamlılık düzeyinin dikkate alınması gerektiği belirtilmektedir (Tabachnick \& Fidell, 2013). Bu incelemeye göre, anlamlılık düzeyi .001'in üzerinde olduğu tespit edilen 24 ölçüm veri setinden çıkarılmıştır. Verilerin normal dağılım gösterdiğinin ölçütü olarak çarpıklık ve basıklık değerlerine bakılmıştır (Tabachnick \& Fidell, 2013). Çarpıklık ve basıklık değerleri (bk. Tablo 1) +1 ve -1 arasında yer aldığı için verilerin normal dağılım gösterdiği sonucuna ulaşılmıştır. Çoklu birlikte değişim varsayımının incelenmesi amacıyla, bağımsız değişkenlerin VIF ve tolerans değerlerine, bağımsız değişkenler arasındaki korelasyon değerlerine bakılmıştır. Buna göre bağımsız değişkenlerin tolerans değerlerinin .80 ile .92 arasında değişmekte olduğu yani .20'den büyük olduğu; VIF değerinin ise 1.084 ile 1.251 arasında değişmekte olduğu yani 10 'dan küçük olduğu görülmüştür. Bağımsız değişkenler arasındaki korelasyon değerlerine bakıldığında ise, en yüksek ilişkinin .90 altında olduğu görülmüștür. Buna göre, bağımsız değişkenler arasında çoklu bağlantı probleminin olmadığı tespit edilmiştir (Tabachnick \& Fidell, 2013). Çoklu regresyon analizinin yapılabilmesi için gerekli varsayımların doğrulandığı ve verilerin regresyon analizine uygun olduğu görülmüştür.

\section{Bulgular}

Araştırmada öncelikle psikolojik sağlamlık bağımlı değişkeni ve benlik saygısı, anne baba tutumları ve akran ilişkileri bağımsız değişkenlerinin puan ortalamaları, standart sapmaları, ranj değerleri ve en büyük, en küçük puanları, çarpıklık ve basıklık değerleri incelenmiştir. Bağımlı ve bağımsız değişkenlere ait betimsel istatistik sonuçları Tablo 1'de verilmiştir.

\section{Tablo 1}

Bağımlı ve Bă̆ımsız Değişskenlerin Betimsel İstatistikleri

\begin{tabular}{|c|c|c|c|c|c|c|}
\hline Değişkenler & $N$ & $\bar{X}$ & $S S$ & Min-Max & Çarpıklık & Basıklık \\
\hline \multicolumn{7}{|l|}{ Bağımlı değişken } \\
\hline Psikolojik sağlamlık & 219 & 101.96 & 8.71 & $78-116$ & -.49 & -.41 \\
\hline \multicolumn{7}{|l|}{ Bağımsız değişkenler } \\
\hline Kabul/ilgi & 219 & 30.52 & 3.73 & $20-36$ & -.58 & -.31 \\
\hline Psikolojik özerklik & 219 & 18.82 & 4.37 & $8-28$ & -.17 & -.47 \\
\hline Kontrol/denetleme & 219 & 19.19 & 3.85 & $9-23$ & -.96 & -.16 \\
\hline Benlik sayg1sı & 219 & 1.05 & 1.22 & $0-5$ & 1.12 & .67 \\
\hline Akran ilişkileri & 219 & 89.51 & 11.49 & $55-110$ & -.78 & .18 \\
\hline
\end{tabular}


Tablo 1 incelendiğinde, özel yetenekli öğrencilerin psikolojik sağlamlık düzeylerinin ortalamasının $101.96(S S=8.71)$ olduğu görülmektedir. Bu ölçekten alınabilen en yüksek puan 116 , en düşük puan ise 78 'dir. Araştırmanın bağımsız değişkenlerinden anne-baba tutum ölçeğinin alt boyutlarının ortalama ve standart sapma değerleri sırasıyla; kabul/ilgi 30.52 ( $S S=3.73)$, psikolojik özerklik $18.82(S S=4.37)$, kontrol/denetleme 19.19'dir $(S S=3.85)$. Özel yetenekli öğrencilerin benlik saygısı düzeylerinin ortalaması $1.05(S S=1.22)$ iken; akran ilişkileri puan ortalamaları 89.51 ( $S S=11.49$ )'dir. Regresyon analizi yapılmadan önce bağımlı değişken ve bağımsız değişkenlerin birbirleriyle olan korelasyonları incelenmiştir. Değişkenlerin Pearson korelasyon katsayıları Tablo 2'de verilmiştir.

\section{Tablo 2}

Bă̆ımlı ve Bă̆ımsız Değişkenler Arasındaki Korelasyon Katsayıları

\begin{tabular}{|c|c|c|c|c|c|c|}
\hline Değişkenler & PS & $\mathrm{K} / \mathrm{I}$ & $\mathrm{PÖ}$ & $\mathrm{K} / \mathrm{D}$ & BS & $\mathrm{A} \dot{\mathrm{I}}$ \\
\hline Psikolojik sağlamlık & 1 & & & & & \\
\hline Kabul/ilgi & $.56^{*}$ & 1 & & & & \\
\hline Psikolojik özerklik & $.38^{*}$ & $.34 *$ & 1 & & & \\
\hline Kontrol/denetleme & .01 & $.07 *$ & $-.07 *$ & 1 & & \\
\hline Benlik saygis1 & $-.46^{*}$ & $-.31 *$ & $-.32 *$ & $-.04 *$ & 1 & \\
\hline Akran ilişkileri & $.46^{*}$ & $.28^{*}$ & $.14 *$ & $.08^{*}$ & $-.21 *$ & 1 \\
\hline
\end{tabular}

Tablo 2 incelendiğinde, özel yetenekli öğrencilerin psikolojik sağlamlıkları ile anne-baba tutumlarının kabul/ilgi ve psikolojik özerklik boyutu, akran ilişkileri, benlik saygıları arasında pozitif yönde ve anlamlı bir ilişki bulunmuştur. Benlik saygısı ölçeğinden alınacak yüksek puan düşük benlik algısı düzeyini gösterdiği için, benlik saygısı negatif bir değer almıştır. Psikolojik sağlamlık ile kontrol/denetleme arasında anlamlı bir ilişki bulunmamıştır. Bu nedenle bu boyut regresyon analizine dâhil edilmemiştir. Araştırmanın yordayıcı değişkenleri olan benlik saygısı, akran ilişkileri ve anne baba tutum ölçeğinin kabul/ilgi ve psikolojik özerklik alt boyutlarının özel yetenekli öğrencilerin psikolojik sağlamlık düzeylerini yordamasına ait çoklu regresyon analizinin bulguları Tablo 3 ve Tablo 4'te verilmiştir.

Tablo 3

Özel Yetenekli Öğrencilerin Psikolojik Sağlamlık Düzeylerinin Yordanmasına İlişkin Bulgular

\begin{tabular}{lcccccccc}
\hline \multicolumn{1}{c}{ Değişkenler } & $N$ & Çoklu $R$ & $R^{2}$ & $R^{2}$ Değişim & $F$ Değişim & $s d 1$ & $s d 2$ & $p$ \\
\hline Kabul/ilgi & & .56 & .31 & .31 & 98.00 & 1 & 217 & .00 \\
Akran ilişkileri & 219 & .64 & .41 & .10 & 38.05 & 1 & 216 & .00 \\
Benlik saygisı & & .70 & .48 & .07 & 28.69 & 1 & 215 \\
Psikolojik özerklik & & .71 & .50 & .02 & 6.74 & 1 & 214 \\
\hline
\end{tabular}

\section{Tablo 4}

Özel Yetenekli Öğrencilerin Psikolojik Sağlamlık Düzeylerinin Yordanmasına İlişkin B, Beta Korelasyonu ve Anlamlllık Düzeyi

\begin{tabular}{|c|c|c|c|c|c|}
\hline Değişken & $B$ & Std. hata & Beta & $t$ & $p$ \\
\hline \multicolumn{6}{|l|}{ 1.Aşama } \\
\hline Sabit & 62.25 & 4.04 & & 15.41 & .00 \\
\hline Kabul/ilgi & 1.30 & .13 & .56 & 9.90 & .00 \\
\hline \multicolumn{6}{|l|}{ 2.Aşama } \\
\hline Sabit & 46.19 & 4.55 & & 10.14 & .00 \\
\hline Kabul/ilgi & 1.08 & .13 & .46 & 8.57 & .00 \\
\hline Akran ilişkileri & .254 & .041 & .33 & 6.17 & .00 \\
\hline \multicolumn{6}{|l|}{ 3.Aşama } \\
\hline Sabit & 56.25 & 4.68 & & 12.02 & .00 \\
\hline Kabul/ilgi & 0.91 & .12 & .39 & 7.34 & .00 \\
\hline Akran ilişkileri & 0.23 & .04 & .30 & 5.75 & .00 \\
\hline Benlik sayg1sı & -1.99 & 0.4 & -0.28 & -5.36 & .00 \\
\hline \multicolumn{6}{|l|}{ 4.Aşama } \\
\hline Sabit & 53.62 & 4.72 & & 11.34 & .00 \\
\hline Kabul/ilgi & .82 & .12 & .35 & 6.52 & .00 \\
\hline Akran ilişkileri & .22 & .04 & .29 & 5.77 & .00 \\
\hline Benlik saygıs1 & -1.76 & .38 & -.25 & -4.67 & .00 \\
\hline Psikolojik özerklik & .28 & .11 & .14 & 2.60 & .01 \\
\hline
\end{tabular}


Regresyon analizi sonuçlarına göre, benlik saygısı, akran ilişkileri ve anne baba tutumu alt boyutları kabul/ilgi ve psikolojik özerklik, özel yetenekli öğrencilerin psikolojik sağlamlık düzeylerini anlamlı bir şekilde yordamaktadır. Yapılan aşamalı çoklu regresyon analizi dört aşamada gerçekleştirilmiştir. Birinci aşamada, özel yetenekli öğrencilerin psikolojik sağlamlık düzeylerinin en yüksek yordayıcısı olan anne baba tutum ölçeğinin kabul/ilgi alt boyutu modele alınmıştır. Kabul/ilgi boyutu tek başına toplam varyansın \%31'ini açıklamıştır. Özel yetenekli öğrencilerin psikolojik sağlamlık düzeyleri ve anne baba tutumlarının kabul/ilgi boyutu arasında pozitif yönde anlamlı ilişki bulunmuştur $\left(R=.56, R^{2}=.31, F(1,22)=98.00, p<.05\right)$. İkinci aşamada akran ilişkileri analize girmiştir. Bu değişkenle birlikte psikolojik sağlamlığın toplam varyansı \%41.4'e yükselmiştir. Akran ilişkileri toplam varyansı \% 10.3 arttırmıştır. Psikolojik sağlamlık ve akran ilişkileri arası da pozitif yönde anlamlı bir ilişsi bulunmuştur $\left(R=.64, R^{2}=.41, F(1,22)=38.05, p<.05\right)$. Üçüncü aşamada, benlik saygısı değişkeni modele dâhil edilmiştir. Benlik saygısı değişkeninin getirdiği ek katkı \%6.9 olup psikolojik sağlamlık toplam varyansı \% 48'e yükselmiştir. Psikolojik sağlamlık ve benlik saygısı arasında negatif yönde anlamlı bir ilişki bulunmuştur $\left(R=.70, R^{2}=.48, F(1,22)=28.69, p<.05\right)$. Benlik saygısının negatif yönde yordamasının sebebi puanın tersten hesaplanıyor olmasıdır. Dördüncü aşamada modele giren anne baba tutumlarından psikolojik özerklik boyutudur. Bu değişkenin getirdiği ek katk1 \%1.6 olup psikolojik sağlamlık toplam varyans1 \%49.9'a yükselmiştir. Psikolojik sağlamlık ve anne baba tutumlarının psikolojik özerklik boyutu arasında pozitif yönde anlamlı bir ilişki bulunmuştur $\left(R=.71, R^{2}=.50, F(1,21)=6.75, p<.05\right)$. Sonuç olarak, özel yetenekli öğrencilerin benlik saygısı, akran ilişkileri, anne baba tutumlarının kabul/ilgi ve psikolojik özerklik boyutunun psikolojik sağlamlık puanlarındaki toplam varyansın \%49.9’unu açıkladığı görülmüştür.

\section{Tartışma}

Araştırmanın amacı özel yetenekli öğrencilerin psikolojik sağlamlık düzeylerinde benlik saygısı, anne baba tutumları ve akran ilişkileri değişkenlerinin yordama gücünü incelemektir. Araştırmada özel yetenekli öğrencilerin benlik saygısı, akran ilişkileri, anne baba kabul/ilgi ve psikolojik özerklik puanlarının psikolojik sağlamlık puanlarındaki toplam varyansın \%50'sini açıkladığı, anne baba tutumları kontrol/denetleme boyutunun ise öğrencilerin psikolojik sağlamlık düzeyleriyle anlamlı bir ilişkisinin olmadığı bulunmuştur. Elde edilen açıklama oranı çok yüksek olarak kabul edilmektedir (Cohen, 1988). Bu bulgular benlik saygısının, aile ve arkadaş ilişkilerinin özel yetenekli öğrencilerin psikolojik sağlamlıklarının açıklanmasında önemli bir güce sahip olduğunu göstermektedir. Araştırmadan elde edilen bulguların tartışılmasında, özel yetenekli öğrencilerle yapılan çalışmalara öncelik verilmiştir. Ancak özel yetenekli öğrencilerin psikolojik sağlamlıklarıyla ilgili çalışmalar sınırlı olduğu için, özel yetenekli öğrencilerin sosyal duygusal özelliklerini ele alan ve özel yetenekli olmayan çocuk/ergenlerle yürütülen araştırmalara da yer verilmiştir.

Araştırmanın anne baba tutumlarına ilişkin bulgularına göre, anne babadan alınan kabul/ilgi ve özerklik desteği çocukların psikolojik sağlamlık düzeylerinin anlamlı birer yordayıcısı iken; kontrol/denetleme değişkeni ise anlamlı bir yordayıcısı değildir. Anne babadan alınan kabul/ilginin özel yetenekli öğrencilerin psikolojik sağlamlığını yordayan en güçlü değişken olduğu ve tek başına toplam varyansın \% 031 'ini açıkladığı görülmüştür. Özel yetenekli çocuklarla yürütülen çalışmalarda da ebeveyn tutumlarının, çocukların yaşadıkları davranışsal problemler ve duygusal zorluklar ile psikososyal uyumları üzerinde etkili olduğu görülmüştür (Dwairy, 2004; Morawska \& Sanders, 2008). Başka bir çalışmada psikolojik sağlamlığı yüksek özel yetenekli öğrencilerin, özerkliklerini güçlendiren ve onları aile dışında destekleyici yetişkinlerle ilişkilerini teşvik eden ebeveynleri olduğu ortaya konulmuştur (Zhang \& Sternberg, 2000). Kim (2015) özel yetenekli öğrencilerin ailelerinden aldıkları desteğin psikolojik sağlamlık için kilit koruyucu faktör olduğunu belirtmektedir. Olgun-Kaval (2014) çalışmasında, üstün yetenekli çocukların normal gelişim gösteren gruba göre, daha fazla otoriter ebeveyn tutumu, ebeveyn reddi, ilgisizlik ve ihmal duyguları algıladığını ortaya koymuştur. Afat (2013) ise, üstün zekâlı çocuğa sahip ebeveynlerin demokratik ve koruyucu tutumu benimseyip; izin verici ve otoriter tutumdan uzak durduklar1 sonucuna ulaşmıştır. Bununla birlikte Yazdani ve Daryei (2016), yetkili ebeveynliğin hem özel yetenekli hem de normal gelişim gösteren ergenlerin uyumu ile pozitif korelasyon gösterirken; otoriter ebeveynliğin sadece özel yetenekli ergenlerin psikososyal uyumunu olumsuz etkilediği sonucuna ulaşmıştır. Benzer şekilde Yıldız (2018) da üstün yetenekli çocukların, akranlarına göre, ebeveyn tutumlarının daha demokratik olduğu sonucuna ulaşmıştır. Ayrıca demokratik ebeveyn tutumunun, psikososyal gelişimi olumlu yönde etkilediğini ve daha az psikososyal sorunun görülmesinde etkili olduğunu ortaya koymuştur. Özel yetenekli çocukların ailelerinin her zaman destekleyici tutum için de olmadığını gösteren çalışmalardan birisinde, üstün yetenekli çocukların ailelerinin başarı konusunda ısrarcı, hatalara karşı eleştirel oldukları, ebeveynin yüksek düzeyde beklentilerinin çocuklarda kaygıya yol açtığı belirtilmiştir (Coşar-Ciğerci, 2006). Aile ortamında iletişimin zayıf, üyeler arası paylaşımın az olmasının, ebeveynlerin daha az aktif ve daha az yakınlık göstermelerinin özel yetenekli çocukların 
gelişimini olumsuz etkilediği ifade edilmektedir (Çağlar, 2004). Özetle, özel yetenekli çocuklarda ebeveyn tutumlarının incelendiği çalışmalar, mevcut araştırmanın sonuçlarıyla tutarlı olacak şekilde, ebeveyn tutumlarının özel yetenekli çocukların sosyal duygusal özellikleri üzerinde etkili olduğunu; psikolojik sağlamlıklarını artırdığını ortaya koymuştur. Ebeveyn tutumlarını ele alan araştırmalar özel yetenekli çocukların gelişimlerini desteklemek için en etkili ebeveynlik stilinin, yetkili/demokratik ebeveynlik olduğunu göstermektedir. Demokratik ebeveynlik stili ise mevcut araştırmada yer alan; ebeveynin kabul ve ilgisini ve özerklik desteğini içermektedir. İlgili alan yazında farklı katılımcılarla yürütülmüş (üniversite öğrencileri, yetişkinler, ergenler) çalışmalarda da aile içi ilişkilerin bireylerin psikolojik sağlamlıklarıyla olan olumlu ilişkisi ortaya konulmuştur (Herbert vd., 2013; Moon vd., 2017; Zakeri vd., 2010; Zhong vd., 2016).

Mevcut araştırmanın bulguları doğrultusunda da özel yetenekli çocukların psikolojik sağlamlığının gelişiminde aileleri ile kurdukları sıcak, yakın, kabul edici ilişkinin, çocukların karşılaştıkları olası sorunların üstesinden gelmelerinde önemli bir koruyucu faktör olduğu söylenebilir. Bu tutuma sahip ebeveynler çocuklarının ihtiyaçlarına ve eş zamanlı olmayan gelişimlerine daha duyarlı, anlayışlı, yardımsever davranarak, onlarla olumlu ve yakın bir ilişki kurarak psikolojik sağlamlık düzeylerinin artmasına katkı sağlayabilir. Freeman (2006) belirttiği gibi, özel yetenekli çocukların, ihtiyaçlarının hem evde hem de okul ortamında fark edilmesi ve kendileriyle samimi iletişim kurmaya hevesli yetişkinler tarafından kabul edilmeleri onları daha dengeli kılmaktadır. Özel yetenekli çocukların duygusal derinliğe sahip olma, duyguları yoğun olarak yaşama, yoğun duygusal tepkiler verme ve aşırı duyarlılık gibi özelliklere sahip olmaları (Saranlı, 2017) nedeniyle anne ve babalarıly bu tür bir ilişki kurmaya daha çok ihtiyaç duydukları ve bu nedenle ebeveynden alınan kabul ve ilginin yüksek bir yordama gücüne sahip olduğu düşünülmektedir.

Bu araştırmanın sonuçları özel yetenekli öğrencilerin anne babalarından aldıkları psikolojik özerkliğin de psikolojik sağlamlık düzeyleri üzerinde etkili olduğunu göstermiştir. Anne babadan alınan psikolojik özerkliğin psikolojik sağlamlık üzerindeki etki büyüklüğünün, kabul ve ilgiye göre daha düşük olmasının önemli olduğu düşünülmektedir. Elde edilen bu sonuç ülkemizde farklı yaş gruplarılla yapılan özerklik ihtiyacı (CihangirÇankaya \& Denizli, 2020; Kandemirci, 2018) ve özerk benlik kurgusu (Özdemir, 2012) kapsamındaki birkaç araştırmayla tutarlılık göstermektedir. Belirtilen araştırmalarda da Türkiye'de yaşayan çocuk ve gençlerin yakınlık, ilişkili olma ihtiyaçlarının, özerklik ihtiyacından daha öncelikli olduğu ortaya konulmuştur. Araştırma bulgularından anne babaların çocuklarını kontrol/denetleme davranışlarının, onların psikolojik sağlamlık düzeyleri üzerinde bir etkisinin olmamasının da önemli olduğu düşünülmektedir. İlgili alan yazında bu bulguyla tutarlılık gösteren çalışmalar (Zakeri vd., 2010) bulunmaktadır. Bu bulgunun ve anne baba tutumlarının çocukların psikolojik sağlamlık düzeyleri üzerindeki farklılaşan etkisinin yorumlanmasında kültürel özelliklerin göz önünde tutulması önemli olduğu düşünülmektedir. Türkiye'nin coğrafi konumu itibariyle Türk aile kültürü hem doğu hem de batı kültüründen izler taşımaktadır. Daha geleneksel ailelerde, aileye yapılan vurgu ve karşılıklı bağlılığın görülmesi, Türk kültürünün toplulukçu yapısına işaret etmektedir (Salman-Engin vd., 2018). Buna göre, araştırma sonucunda kabul/ilgi boyutunun toplam varyanstaki \%31'lik açılayıcıllğın da kültürümüzde bireylerin aile tarafından kabul/ilgi görme ihtiyacının ve aile aidiyetinin yüksek olmasının payının olabileceği düşünülmektedir. Belirtilen kültürel yapı, anne baba tutumlarından psikolojik özerklik boyutunun çocukların psikolojik sağlamlık düzeyleri üzerinde çok daha düşük yordama gücüne (1.6) sahip olmasını da açıklamaktadır. Çünkü toplulukçuluğun, bağlılık ihtiyacı ile pozitif, özerklik ihtiyacı ile negatif ilişkili olduğu belirtilmektedir (Hui \& Villareal, 1989). Etki gücü düşük olmakla birlikte özel yetenekli öğrencilerin anne babalarından aldıkları özerklik desteğinin psikolojik sağlamlık düzeyleriyle olumlu ilişkisi, özerklik desteğinin kişiye seçim yapma firsatı sağlaması, kişinin özerk iradesiyle davranmasına, değerleri özümsemesine ve içsel motivasyonla hareket etmesine izin vermesiyle açıklanabilir (Kındap, 2011). Bütün bu kazanımlar ise onun psikolojik olarak daha sağlam olmasına yol açmaktadır.

Anne baba tutumlarından kontrol/denetleme ve psikolojik özerklik boyutu birbiriyle bağlantılıdır. Çünkü özerkliğe dayalı davranışlarda seçimden, kontrole dayalı davranışlarda ise uyma ve boyun eğmeden söz edilmektedir (Deci vd., 1991). Ancak araştırma bulgularında psikolojik özerklik boyutunun psikolojik sağlamlığı istatistiksel olarak anlamlı bir biçimde yordadığı görülürken, kontrol/denetleme boyutunda elde edilen sonucun istatiksel olarak anlamlı olmadığı görülmektedir. Belirtilen kültürel yapı nedeniyle çocukların anne babalarının denetleme davranışlarını olumsuz algılamadığı ne olumlu ne olumsuz olacak şekilde olağan kabul ettiği düşünülmektedir. Benzer bulgulara Türkiye'de yapılan başka bir çalışmayla da ulaşılmış ve çocukların öğretmenlerinin kendilerine yönelik kontrolcü davranışlarını olumsuz olarak değil aksine öğretmenin kendilerini sevdikleri için öyle davrandıkları biçiminde yorumladıkları görülmüştür (Kandemirci, 2018). Araştırmadan elde edilen bulgular, akran ilişkilerinin özel yetenekli öğrencilerin psikolojik sağlamlık düzeyini pozitif yönde anlamlı 
bir şekilde yordadığını göstermektedir. Buna göre akran ilişkileri puanları yüksek olan özel yetenekli öğrencilerin psikolojik sağlamlıklarının da yüksek olduğu söylenebilir. Bu sonuç akran kabulünün güçlü bir koruyucu faktör olarak risk altındaki çocukların uyumuna yardımcı olabileceği (Criss vd., 2002) bulgusunu desteklemektedir. Akademik olarak özel yetenekli öğrencilerin psikolojik sağlamlıklarının incelendiği bir araştırmada, öğrencilerin arkadaşlarından aldıkları desteğin öğrencilerin psikolojik sağlamlık düzeyleri için anlamlı bir yordayıcı olduğu bulunmuştur (Chen vd., 2017). Alanyazında, arkadaşlık ilişkilerinin akademik sağlamlığın (Gizir, 2004) ve psikolojik sağlamlığın (Gökden-Kaya, 2007) yordayıcısı olduğuna ve psikolojik sağlamlık düzeyi yüksek olan bireylerin arkadaşlık ilişkilerinde kendini algılama yeterliliklerinin yüksek olduğuna (Jew vd., 1999) dair bulgular yer almaktadır. Ayrıca akademik ve yaratıcı yeteneklerin gelişsiminde akran ilişkilerinin olumlu bir etkisi olduğunu belirten araştırma sonuçları bulunurken (Lee, 2002); akran ilişkilerinin özel yetenekli öğrenciler için zorlu deneyimler olabileceği de belirtilmektedir (Peterson vd., 2009). Özellikle akademik olarak özel yetenekli olan öğrencilerin akranlarıyla sosyal ilişkilerini engelleyebilecek yaşantıları olabileceği (Wandansari, 2011); özel yetenekli ergenlerin, akranları tarafından ifade edilen damgalamanın farkında oldukları (Rimm, 2002) ortaya konulmuştur. Bu doğrultuda özel yetenekli öğrencilerin akran ilişkilerinin güçlendirilmesine yönelik çalışmalar yürütmenin önemli olduğu ve onların psikolojik sağlamlık düzeylerine katkı getireceği söylenebilir.

Alan yazında, özel yetenekli öğrencilerin akran ilişkilerinin, iyi oluş, yaşam doyumu ve sosyal uyum düzeyleriyle ilişkisinin incelendiği araştırmalar da yer almaktadır. Erol (2015), üstün zekâlı ergenlerin, akran ilişkileri ile öznel iyi oluşları arasında anlamlı bir ilişki bulmuş, bu öğrencilerin akranlarına bağlılıkları ile ilişki doyumu, yaşam doyumu ve olumlu duyguları arasında da anlamlı bir ilişki olduğu sonucuna ulaşmıştır. BapoğluDümenci (2018) ise, sosyal beceri eğitim programının, üstün zekâlı ve yetenekli çocuklarda, akran ilişkilerinin gelişimine yönelik olarak iletişim, etkileşim, güven ve genel akran ilişkilerinde etkili olduğu, birliktelik boyutunda ise etkili olmadığını ortaya koymuştur. Başka bir araştırmada ise, üstün zekâlı öğrencilerin arkadaşlık ilişkilerini geliştirmek için hazırlanan programın, arkadaşlık ilişkilerini olumlu yönde etkilediği belirtilmiştir (Uysaler, 2015). Sonuç olarak, özel yetenekli öğrencilerin akran ilişkilerinin, psikolojik sağlamlık gibi pozitif değişkenlerle de ilişkili olduğu görülmüştür. Buna göre, özel yetenekli öğrencilerin özel yetenekli olmalarından kaynaklı bireysel ve ailesel zorluklarla baş etmelerinde, akran kabulünü ve desteğini içeren akran ilişkilerinin, koruyucu bir faktör olarak, kritik bir öneme sahip olduğu düşünülmektedir.

Araştırmada özel yetenekli öğrencilerin benlik saygısının psikolojik sağlamlık düzeylerini anlamlı bir şekilde yordadığı bulunmuştur. Bu çerçevede benlik saygısı yüksek olan özel yetenekli öğrencilerin psikolojik sağlamlıklarının da yüksek olduğu söylenebilir. Araştırma bulgusuyla tutarlı olacak şekilde, psikolojik sağlamlığı destekleyen bir faktör olan öz-yeterliğin zekanın ötesinde önemli bir katkı sağladığı ifade edilmektedir (Sternberg vd., 2001). Akademik olarak özel yetenekli öğrencilerin psikolojik sağlamlıklarıyla ilgili yapılan bir çalışmada, öğrencilerin kişisel özelliklerinin (umut, yaratıcılık ve merak) psikolojik sağlamlıklarıyla ilişkili olduğu görülmüştür (Chen vd., 2017). Özel yetenekli öğrencilerin düşük öz-yeterlik düzeylerinin ise, anlama, sentezleme, uygulama ve değerlendirme gibi bilişsel becerilerin gelişimi üzerinde olumsuz bir etkiye sahip olacağ 1 ve bunun da yüksek düzeyde kaygıya yol açacağı biçiminde açıklanmaktadır (Tebbs \& Subhi-Yamin, 2006). İlgili alan yazında genel popülasyonda yürütülen çalışmalarda da psikolojik olarak sağlam bireylerin yüksek benlik saygısına sahip olduğu (Benetti \& Kambouropoulos, 2006; Buckner vd., 2003; Dumont \& Provost, 1999; Fergusson \& Lynskey, 1996; Masten \& Coatsworth, 1998) ve benlik saygısının psikolojik sağlamlığın yordayıcısı olduğu (Balgiu, 2017; Bayköse vd., 2017; Eryılmaz, 2012) görülmüştür. Albayrak-Dengiz (2014), üstün zekâlı ve üstün yetenekli öğrencilerde, aileden algılanan sosyal destek düzeyinin benlik saygısını etkilediği, arkadaş ve öğretmenden algılanan sosyal destek düzeyinin benlik saygısını etkilemediğini bulmuştur. Bencik (2006) ise, üstün yetenekli çocuklarda, mükemmeliyetçilik arttıkça benlik saygısının azaldığı sonucuna ulaşılmıştır. Erol (2004), Fen lisesi örneklemi üzerinde, üstün yeteneklilerde, duygusal zekâ ile benlik saygısı arasında olumlu bir ilişki bulmuş olup benlik saygısı artarken duygusal zekâ düzeyinin de arttığı belirtmiştir. Topçu (2015) ise, araştırmasının katılımcılarını oluşturan üstün zeka ve normal zeka düzeyine sahip öğrencilerin, benlik saygısı ve içsel motivasyon düzeyi arasında pozitif yönde anlamlı bir ilişki; benlik saygısı ve dışsal motivasyon düzeyi arasında ise negatif yönde anlamlı bir ilişki bulmuştur. Bu araştırma sonuçlarına göre, özel yetenekli öğrencilerin benlik saygısının pek çok faktör tarafından etkilendiğini ve birçok faktörü de etkilediği söyleyebilir. Bu araştırma sonuçlarından yola çıkarak özel yetenekli öğrencilerin yüksek benlik saygısına sahip olmalarının, psikolojik sağlamlık düzeylerine katkı sağlayacağı söylenebilir. Benlik saygısının yüksekliği özel yetenekli öğrencilerin yeteneklerine inanmalarını, yetenekleri doğrultusunda ilerlemek için kendilerine güven duymalarını ve yeteneklerini yaratıcı bir şekilde sergileyebilmelerini sağlayabilir. 
Araştırmanın bazı sınılılıkları bulunmaktadır. Bunlardan birisi, araştırmanın örnekleminin tek bir ildeki Bilim ve Sanat Merkezlerine devam eden öğrencilerden oluşmasıdır. Araştırma korelasyonel bir çalışma olduğundan, analizler sonucu ulaşılan bulguların nedensellik değil ilişkisellik çerçevesinde değerlendirilmesi araştırmanın bir diğer sınırlılı̆̆ı kabul edilebilir.

Sonuç olarak araştırma bulguları özel yetenekli öğrencilerin psikolojik sağlamlık düzeylerini, dışsal koruyucu faktörlerin (anne babadan alınan kabul/ilgi ve akran ilişkileri) daha güçlü bir biçimde açıkladığını ve içsel bir koruyucu faktör olan benlik saygısının da anlamlı bir biçimde yordadığını ortaya koymuştur. Özel yetenekli öğrencilerin psikolojik sağlamlığının, kişiliğin belirli özelliklerinin ve koruyucu özelliklerin birleşiminden kaynaklandığı (Alexopoulou vd., 2019) bulgusuyla tutarlı sonuçlar elde edilmiştir. Çalışmanın bulguları, özel yetenekli öğrencilerin karșılaştıkları risk faktörleriyle baş etmelerinde, yakınlık ve kabule dayalı aile ilişkilerinin rolünün güçlü olduğunu göstermiştir. Bu doğrultuda özel yetenekli öğrencilerin ebeveynleriyle aile atmosferinde kabul, ilgi, sıcaklığın artırılmasına yönelik psiko-eğitim çalışmalarının (ör. Kahraman \& Tanrıkulu, 2019; Saranlı \& Metin, 2014) yürütülmesi yararlı olacaktır. Araştırmada akran ilişkilerinin ve benlik saygısının öğrencilerin psikolojik sağlamlık düzeylerini etkileyen değisskenler olduğu bulunmuștur. Bu kapsamda özel yetenekli öğrencilerin kişisel sosyal gelişimlerinin desteklenmesine yönelik grup çalışmaları planlanabilir. Pfeiffer ve Stocking (2000), psikolojik sağlamlıklarını artırmak için kapsamlı eğitimsel ve sosyal firsatların sağlanması gerektiğini de öne sürmüştür. Okullarda özel yetenekli çocuklarla yürütülecek önleme ve müdahale çalışmaları ile bunun mümkün olabileceği düşünülmektedir. Bu çalışma ülkemizde özel yetenekli öğrencilerde psikolojik sağlamlığın araştırıldığı ilk çalışmalardan birisidir. Yapılacak yeni araştırmalarla, özellikle nitel çalışmalarla, özel yetenekli öğrencilerin psikolojik sağlamlığının derinlemesine incelenmesi mümkün olacaktır. Ülkemizde daha geniş örneklem gruplarıyla ve farklı alanlarda özel yeteneğe sahip çocuklar, akademik başarısı düşük özel yetenekli çocuklar gibi spesifik gruplarla yapılacak yeni çalışmalar, bu araştırmanın bulgularını da yeniden tartı̧̧maya imkân verecektir.

\section{Yazarların Katkı Düzeyleri}

Araştırma yüksek lisans tezinin özeti niteliğindedir. Araştırma konusu ve araştırma yöntemi her iki yazar tarafından belirlenmiş̧ir. Veri toplama ve veri analizi çalışmaları birinci yazar tarafından, araştırma raporunun yazımı, sorumlu yazar ağırlıklı olmak üzere, her iki yazar tarafından yapılmıştır. 


\section{Kaynaklar}

Afat, N. (2013). Üstün zekâll çocukların ebeveynlerine yönelik gelişstirilen aile eğitim programının etkililiğinin sinanmast [Evaluating effectiveness of family education program for the gifted children's parents] (Tez Numarası: 350097) [Doktora tezi, İstanbul Üniversitesi]. Yükseköğretim Kurulu Ulusal Tez Merkezi.

Alkan, A. (2013). Öğretmenler için “üstün zekâllyetenekli öğrencilerin belirlenmesi eğitim yazılımı”nın gelişstirilmesi ve değerlendirilmesi [For teachers "identification of gifted/talented students educational software" development and evaluation] (Tez Numarasi: 333466) [Doktora tezi, Gazi Üniversitesi]. Yükseköğretim Kurulu Ulusal Tez Merkezi.

Albayrak-Dengiz, N. (2014). Üstün zekâll ve üstün yetenekli çocuklarda algllanan sosyal destek düzeyinin benlik saygisina etkisinin incelenmesi [The effect of the perceived social support level on self-esteem in gifted and talented children] (Tez Numarasi: 372179) [Yüksek lisans tezi, Akdeniz Üniversitesi]. Yükseköğretim Kurulu Ulusal Tez Merkezi.

Alexopoulou, A., Batsou, A., \& Drigas, A. (2019). Resilience and academic underachievement in gifted students: Causes, consequences and strategic methods of prevention and intervention. International Journal of Online and Biomedical Engineering, 15(14), 78-86. https://doi.org/10.3991/ijoe.v15i14.11251

Altman, R. (1983). Social-emotional development of gifted children and adolescents: A research model. Roeper Review, 6(2), 65-68. https://doi.org/10.1080/02783198309552757.

Altun, F., \& Yazıcı, H. (2012). Üstün yetenekli öğrencilerin benlik kavramları ve akademik öz-yeterlik inançları: Karşılaştırmalı bir çalışma [Self-concept and academic self-efficacy beliefs of gifted students: A comparative study]. Mehmet Akif Ersoy Üniversitesi Eğitim Fakültesi Dergisi, 1(23), 319-334 https://dergipark.org.tr/en/download/article-file/181380

Balcı, İ. (2018). Çocukluk çă̆ı travmaları ile baş etme yönelimli psiko-eğitim programının psikolojik sağlamlık üzerindeki etkisi [The impact of coping with childhood traumas oriented psycho-education program on resilience] (Tez Numarasi: 511061) [Doktora tezi, Karadeniz Teknik Üniversitesi]. Yükseköğretim Kurulu Ulusal Tez Merkezi.

Balgiu, B. A. (2017). Self esteem, personality and resilience. Study of a students emerging adults group. Journal $\begin{array}{lllll}\text { of Educational } & \text { Sciences and Psychology, } & \text { 7(1), }\end{array}$ https://www.researchgate.net/publication/318379139

Bapoğlu-Dümenci, S. S. (2018). Üstün zekalı ve yetenekli çocukların akran ilişkilerine sosyal beceri eğitim programinin etkisinin incelenmesi [Examining the effects of social skills training on the gifted and talented children's peer relations] (Tez Numarasi: 505352) [Doktora tezi, Ankara Üniversitesi]. Yükseköğretim Kurulu Ulusal Tez Merkezi.

Bayköse, N., Civar-Yavuz, S., Keskin, P., \& Kılınç, M. (2017). Sporcularda benlik saygısı ve tutkunluğun psikolojik sağlamlığı yordamadaki rolü: Bir yapısal eşitlik modeli uygulaması [The role of self-esteem and passion in determining resilience in athletes: An application of structural equation modelling]. International Journal of Sports Exercise \& Training Sciences, 3(4), 169-177. https://doi.org/10.18826/useeabd.327186

Bencik, S. (2006). Üstün yetenekli çocuklarda mükemmeliyetçilik ve benlik algısı arasındaki iliş̧kinin incelenmesi [Investigation of the relationship between perfectionism and self-concept in gifted children] (Tez Numarasi: 192729) [Yüksek lisans tezi, Hacettepe Üniversitesi]. Yükseköğretim Kurulu Ulusal Tez Merkezi.

Benetti, C., \& Kambouropoulos, N. (2006). Affect-regulated indirect effects of trait anxiety and trait resilience on self-esteem. Personality and Individual Differences, 41(2), 341-352. https://doi.org/10.1016/j.paid.2006.01.015

Bildiren, A. (2018). Özel eğitimin üstün yetenekli çocuklar üzerinde benlik algısına etkisi [The effect of special education on self-perception on gifted children]. Kastamonu Educational Journal, 26(5), 1489-1496, https://doi.org/10.24106/kefdergi.397345

Bişgin, V. (2013). Pozitif psikoloji [Positive psychology]. Onto Dergisi, 1, 22-23. https://www.ontodergisi.com/sayilar/pozitif-psikoloji 
Buckner, J. C., Mezzacappa, E., \& Beardslee, W. R. (2003). Characteristics of resilient youths living in poverty: The role of self regulatory processes. Development and Psychopathology, 15(1), 139-162. https://doi.org/10.1017/S0954579403000087

Buescher, T. M. (1985). A framework for understanding the social and emotional developmentof gifted and talented adolescents. Roeper Review, 8(1), 10-15. https://doi.org/10.1080/02783198509552919

Bukowski, W. M., Hoza, B., \& Boivin, M. (1994). Measuring friendship quality during pre and early adolescence: The development and psychometric properties of the Friendship Qualities Scale. Journal of Social and Personal Relationships, 11(3), 471-484. https://doi.org/10.1177/0265407594113011

Bulut, S., Doğan, U., \& Altundağ, Y. (2013). Adolescent Psychological Resilience Scale: Validity and reliability study. Suvremena Psihologija, 16(1), 21-32. https://www.researchgate.net/publication/281061242

Bumpus, J. A. (2014). Transracial adoption: Racial identity, resilience and self esteem of African American adoptees [Doctoral dissertation, Antioch University]. https://aura.antioch.edu/etds/101

Büyüktaşkapu-Soydan, S., \& Kabar, E. (2020). Üstün yetenekli çcoukların düşünce içeriklerinin incelenmesi [Investigation of thought contents of gifted children]. KTO Karatay Üniversitesi Sağllk Bilimleri Dergisi, 1(1), 34-43. https://dergipark.org.tr/tr/download/article-file/1067377

Cihangir-Çankaya, Z., \& Denizli, S. (2020). An explanation of happiness with secure attachment, basic psychological needs and hope: The case of Turkish university students. European Journal of Educational Research, 9(1), 433-444. https://dx.doi.org/10.12973/eu-jer.9.1.433

Clonan, S. M., Chafouleas, S. M., McDougal, J. L., \& Riley-Tillman, T. C. (2004). Positive psychology goes to school: Are we there yet? Psychology in the Schools, 41(1), 101-110. https://doi.org/10.1002/pits.10142

Chen, X., Cheung, H. Y., Fan, X., \& Wu, J. (2017). Factors related to resilience of academically gifted students in the Chinese cultural and educational environment. Psychology in the Schools, 55(2), 107-119. https://doi.org/10.1002/pits.22044

Cohen, J. (1988). Statistical power and analysis for the behavioral sciences (2nd ed.). Lawrence Erlbaum Associates.

Coşar-Ciğerci, Z. (2006). Üstün yetenekli olan ve olmayan ergenlerde benlik saygısı, başkalarının algılaması ve psikolojik belirtiler arasindaki ilişkiler [To compare self-esteem, being perceived by others and psychologic indications in adolescent who are gifted or not] (Tez Numaras1: 186799) [Yüksek lisans tezi, Sakarya Üniversitesi]. Yükseköğretim Kurulu Ulusal Tez Merkezi.

Criss, M. M., Pettit, G. S., Bates, J. E., Dodge, K. A., \& Lapp, A. L. (2002). Family adversity, positive peer relationships and children's externalizing behavior: A longitudinal perspective on risk and resilience. Children Development, 73(4), 1220-1237. https://doi.org/10.1111/1467-8624.00468

Çağlar, D. (2004). Üstün zekâlı çocukların özellikleri. M. R. Şirin, A. Kulaksızoğlu, \& A. E. Bilgili (Eds.), Üstün yetenekli çocuklar seçilmiş makaleler kitabı [A book of selected articles about gifteed children] içinde (ss. 111-220). Çocuk Vakfı Yayınları.

Çeçen, A. R. (2008). Üniversite öğrencilerinde yaşam doyumunu yordamada bireysel bütünlük (tutarlılık) duygusu, aile bütünlük duygusu ve benlik saygısı [Sense of coherence, family sense of coherence and self esteem in predicting life satisfaction among university students]. Eğitimde Kuram ve Uygulama, 4(1), 1930. https://dergipark.org.tr/en/download/article-file/63251

Çuhadaroğlu, F. (1986). Adolesanlarda benlik saygısı [Self esteem in adolescents] [Yayımlanmamış yüksek lisans tezi]. Hacettepe Üniversitesi.

Deci, E. L., Vallerand, R. J., Pelletier, L. G., \& Ryan, R. M. (1991). Motivation and education: The selfdetermination perspective. Educational Psychologist, 26(3-4), 325-346. http://selfdeterminationtheory.org/SDT/documents/1991_DeciVallerandPelletierRyan_EP.pdf

Dixon, F. A., Cross, T. L., \& Adams, C. M. (2001). Psychological characteristics of academically gifted students in a residential setting: A cluster analysis. Psychology in the Schools, 38(5), 433-444. https://doi.org/10.1002/pits.1032 
Dole, S. (2000). The implications of the risk and resilience literature for gifted students with learning disabilities. Roeper Review, 23(2), 91-96. https://doi.org/10.1080/02783190009554074

Dumont, M., \& Provost, M. A. (1999). Resilience in adolescent: Protective role of social support, coping strategies, self-esteem and social activities on experience and depression. Journal of Youth and Adolescence, 28(3), 343-363. https://doi.org/10.1023/A:1021637011732

Dwairy, M. (2004). Parenting styles and mental health of Arab gifted adolescents. Gifted Child Quarterly, 48(4), 275-286. https://doi.org/10.1177/001698620404800403

Eminağaoğlu N. (2006). Güç koşullarda yaşayan sokak çocuklarında dayanıklılık (să̆lamlık) [Resilience (hardiness) of street childeren living in difficult conditions] (Tez Numaras1: 205267) [Doktora tezi, Ege Üniversitesi]. Yükseköğretim Kurulu Ulusal Tez Merkezi.

Er, G. (2009). Ailesi parçalanmış olan ilköğretim ikinci kademe öğrencilerinin akademik să̆lamlık düzeylerinin bazl değişkenlere göre yordanması [Predicting the academic resilience levels of 2nd level primary educations students who have broken family according to some variables] (Tez Numaras1: 241417) [Yüksek lisans tezi, Ege Üniversitesi]. Yükseköğretim Kurulu Ulusal Tez Merkezi.

Erol, B. (2004). Üstün yeteneklerde duygusal zekâ ile benlik saygısı arasındaki ilişki [The relationship between emotional intelligence and self-esteem of the gifted science hight school students] (Tez Numaras1: 147091) [Yüksek lisans tezi, Karadeniz Teknik Üniversitesi]. Yükseköğretim Kurulu Ulusal Tez Merkezi.

Erol, F. (2015). Üstün zekâlı ergenlerin akran ilişkileri ile öznel iyi oluşları arasındaki ilişkinin incelenmesi [Investigation of the relationship between peer relationships and subjective well-being of gifted adolescents] (Tez Numarası: 414412) [Yüksek lisans tezi, Marmara Üniversitesi]. Yükseköğretim Kurulu Ulusal Tez Merkezi.

Eryılmaz, S. (2012). Üniversite öğrencilerinde psikolojik sağlamlı̆̆ yordamada, yaşam doyumu, benlik saygısl, iyimserlik ve kontrol odağının incelenmesi [University of students predictive in psychological resilience to investigate life satisfaction, self respect, optimism and locus of control] (Tez Numaras1: 326020) [Yüksek lisans tezi, Muğla Sıtkı Koçman Üniversitesi]. Yükseköğretim Kurulu Ulusal Tez Merkezi.

Erkan-Atik, Z., Çok, F., Esen-Çoban, A., Doğan, T., \& Güney-Karaman, N. (2014). Akran İlişkileri Ölçeği’nin Türkçeye uyarlanması: Geçerlik ve güvenirlik çalışması [The Turkish adaptation of the Friendship Qualities Scale: A validity and reliability study]. Kuram ve Uygulamada Ĕgitim Bilimleri, 14(2), 433446. https://toad.halileksi.net/sites/default/files/pdf/akran-iliskileri-olcegi-toad.pdf

Freeman, J. (1983). Emotional problems of the gifted child. Journal of Child Psychology and Psychiatry, 24(3), 481-485. https://doi.org/10.1111/j.1469-7610.1983.tb00123.x

Freeman, J. (2006). The emotional development of gifted and talented children. Gifted and Talented International, 21(2), 20-28. https://doi.org/10.1080/15332276.2006.11673472

Fergusson, D. M., \& Lynskey, M. T. (1996). Adolescent resiliency to family adversity. Journal of Child Psychology and Psychiatry, 37(3), 281-292. https://doi.org/10.1111/j.1469-7610.1996.tb01405.x

Fraenkel, J. R., \& Wallen, N. E. (2009). How to design and evaluate research in education. McGraw-Hill.

Fraser, M. W., Galinsky, M. J., \& Richman, J. M. (1999). Risk, protection and resilience: Toward a conceptual framework for social work practice. Social Work Research, 23(3), 131-143. https://doi.org/10.1093/swr/23.3.131

Gallagher, J. J. (1990). Editorial: The public and professional perception of the emotional status of gifted children. Journal for the Education of the Gifted, 13(3), 202-211. https://doi.org/10.1177/016235329001300302

Gizir, C. A. (2004). Academic resilience: An investigation of protective factors contributing to the academic achievement of eight grade students in poverty (Tez Numarası: 147608) [Yüksek lisans tezi, Orta Doğu Teknik Üniversitesi]. Yükseköğretim Kurulu Ulusal Tez Merkezi. 
Gizir, C. A. (2007). Psikolojik sağlamlık, risk faktörleri ve koruyucu faktörler üzerine bir derleme çalışması [A literature review of studies on resilience, risk, and protective factors]. Türk Psikolojik Danışma ve Rehberlik Dergisi, 3(28), 113-128. https://dergipark.org.tr/tr/download/article-file/200204

Gökden-Kaya, N. (2007). The role of self-esteem, hope and external factors in predicting resilience among regional boarding elementary school students (Tez Numarası: 217827) [Yüksek lisans tezi, Orta Doğu Teknik Üniversitesi]. Yükseköğretim Kurulu Ulusal Tez Merkezi.

Graber, R., Pichon, F., \& Carabine, E. (2015). Psychological resilience: State of knowledge and future research agendas. Overseas Development Institute.

Gürgan, U. (2006). Grupla psikolojik danışmanin üniversite ögrencilerinin yllmazlık düzeylerine etkisi [The effect of the group program of resiliency level of university students] (Tez Numarası: 205194) [Doktora tezi, Ankara Üniversitesi]. Yükseköğretim Kurulu Ulusal Tez Merkezi.

Helt, C. A. (2008). The role of IQ and gender in the social-emotional functioning of adolescents [Unpublished doctoral dissertation]. University of Northern Colorado.

Herbert, H. S., Manjula, M., \& Philip, M. (2013). Growing up with a parent having schizophrenia: Experiences and resilience in the offsprings. Indian Journal of Psychological Medicine, 35(2), 148-153. https://www.researchgate.net/publication/256765080_Growing_Up_with_a_Parent_having_Schizophre nia Experiences and Resilience in the Offsprings

Herrman, H., Stewart, D. E., Diaz-Granados, N., Berger, E. L., Jackson, B., \& Yuen, T. (2011). What is resilience? Canadian Journal of Psychiatry, 56(5), 258-265. https://doi.org/10.1177/070674371105600504

Hui, C. H., \& Villareal, M. J. (1989). Individualism-collectivism and psychological needs: Their relationships in two cultures. Journal of Cross-Cultural Psychology, 20(3), 310-323. https://doi.org/10.1177/0022022189203005

Işık, Ş. (2016). Türkiye'de kendini toparlama gücü konusunda yapılmış araştırmaların incelenmesi [Analysis of the studies in the field of resilience published in Turkey]. Türk Psikolojik Danışma ve Rehberlik Dergisi, 6(45), 65-76. https://dergipark.org.tr/tr/pub/tpdrd/issue/42745/515929

Jew, C. L., Green, K. E., \& Kroger, J. (1999). Development and validation of a measure of resiliency. Measurement and Evaluation in Counseling and Development, 32(2), 75-89. https://doi.org/10.1080/07481756.1999.12068973

Kahraman, S., \& Tanrikulu, T. (2019). The effectiveness of a psychoeducational program on parents' communication with their gifted children. Turkish Journal of Giftedness and Education, 9(1), 32-46. https://www.researchgate.net/publication/334807619 The Effectiveness_of_a_Psychoeducational_Pro gram_on_Parents\%27_Communication_with_their_Gifted_Children_Ebeveynin_Ustun_Yetenekli_Coc uguyla_Iletisimini_Gelistirmeye_Yonelik_Psiko-egitim_Programinin_Etki

Kahvecioğlu, K. (2016). Özel yetenekli çocuğu olan ebeveynlerin psikolojik sağlamlıklarının bazı değişkenler açısından incelenmesi [Examination of factors which are efecting resiliency of parents who have gifted] (Tez Numarası: 432645) [Yüksek lisans tezi, Beykent Üniversitesi]. Yükseköğretim Kurulu Ulusal Tez Merkezi.

Kandemirci, D. (2018). Sinıf ögrretmenlerine yönelik özerklik desteği eğitim programının etkililiğ̈inin incelenmesi [Examining the efectiveness of a teacher training program on autonomy support] (Tez Numaras1: 503211) [Doktora tezi, Ege Üniversitesi]. Yükseköğretim Kurulu Ulusal Tez Merkezi.

Karaırmak, Ö. (2006). Psikolojik sağlamlık, risk faktörleri ve koruyucu faktörler [Resilience, risk and protective factors]. Türk Psikolojik Danışma ve Rehberlik Dergisi, 3(26), 129-142. https://dergipark.org.tr/tr/pub/tpdrd/issue/21446/229856

Karakuş, F. (2010). Üstün yetenekli çocukların anne babalarının karşılaştıkları güçlükler [Difficulties that families of gifted students face]. Mersin Üniversitesi Eğitim Fakültesi Dergisi, 6(1), 127-144. https://dergipark.org.tr/tr/download/article-file/160766

Karasar, N. (2014). Bilimsel araştırma yöntemi [Scientific research method] (13. baskı). Nobel Yayıncılık 
Karatay, İ. (2018). Özel yetenekli öğrencilerin aile içi ilişkileri ile benlik algısı arasındaki ilişkinin incelenmesi [The investigation of the relationship between family relations and self perceptions of special talented (gifted) students] (Tez Numarası: 520115) [Yüksek lisans tezi, İstanbul Sabahattin Zaim Üniversitesi]. Yükseköğretim Kurulu Ulusal Tez Merkezi.

Kaul, C. R., Hardin, K. A., Farah, Y. N., \& Johnsen, S. K. (2015). What the research says about gifted students' resilience. Journal of the Texas Association for the Gifted \& Talented, 36(3), 25-34. https://www.txgifted.org/files/2015-3.pdf

Kındap, Y. (2011). Kendini belirleme kuramı temelinde ergenlikte destekleyici ebeveynlik, akademik ve sosyal uyum ve kendini belirleme düzeyi arasındaki ilişkilerin boylamsal olarak incelenmesi [A longitudinal study of the relationships between supportive parenting, social adjustment and self determition level among adolescents on the basis of self determination theory] (Tez Numaras1: 288225) [Doktora tezi, Hacettepe Üniversitesi]. Yükseköğretim Kurulu Ulusal Tez Merkezi.

Kidd, S., \& Shahar, G. (2008). Resilience in homeless youth: The key role of self esteem. American Journal of Orthopychiatry, 78(2), 163-172. https://doi.org/10.1037/0002-9432.78.2.163

Kim, M. (2015). Enhancing resilience of gifted students. Texas Association for the Gifted \& Talented Article, 36(3), 17-21. $\quad$ https://scholarworks.wm.edu/cgi/viewcontent.cgi?referer= https://www.google.com/\&httpsredir=1\&article=1092\&context=articles

King, L. G. (2009). The importance of failing well: An exploration of the relationship between resilience and academic achievement [Master thesis, The University of Waikato]. https://hdl.handle.net/10289/2807

Kitano, M. K., \& Lewis, R. B. (2005). Resilience and coping: Implications for gifted children and youth at risk. Roeper Review, 27(4), 200-205. https://doi.org/10.1080/02783190509554319

Kline, B. E., \& Short, E. B. (1991). Changes in emotional resilience: Gifted adolescent females. Roeper Review, 13(3), 118-121. https://doi.org/10.1080/02783199109553333

Koç, İ. (2015). The remarks of gifted students attending science and art center about communication skills. Journal of Gifted Education Research, 1(3), 39-53. https://silo.tips/download/the-remarks-of-gifted-studentsattending-science-and-art-center-about-communicat

Koçak, R., \& İçmenoğlu, E. (2012). Üstün yetenekli öğrencilerin duygusal zekâ ve yaratıcıllk düzeylerinin yaşam doyumlarını yordayıc1 rolü [Emotional intelligence and creativity as predictors of life satisfaction among gifted students]. Türk Psikolojik Danışma ve Rehberlik Dergisi, 4(37), 73-85. https://dergipark.org.tr/tr/pub/tpdrd/issue/21457/229659

Lamborn, S. D., Mounts, N. S., Steinberg, L., \& Dornbusch, S. M. (1991). Patterns of competence and adjustment among adolescents from authoritative, authoritarian, indulgent and neglectful families. Child Development, 62(5), 1049-1065. https://doi.org/10.2307/1131151

Lee, S. Y. (2002). The effects of peers on the academic and creative talent development of a gifted adolescent male. Journal of Secondary Gifted Education, 14(1), 19-29. https://doi.org/10.4219/jsge-2002-387

Lee, J. H., Nam, S. K., Kim, A-R., Kim, B., Lee, M. Y., \& Lee, S. M. (2013). Resilience: A meta-analytic approach. Journal of Counseling \& Development, 91(3), 269-279. https://doi.org/10.1002/j.15566676.2013.00095.x

Luthar, S. S. (1991). Vulnerability and resilience: A study of high-risk adolescents. Child Development, 62(3), 600-616. https://doi.org/10.2307/1131134

Luthar, S. S., \& Zigler, E. (1991). Vulnerability and competence: A review of research on resilience in childhood. American Orthopsychiatric Association, 61(1), 6-22. http://dx.doi.org/10.1037/h0079218

Masten, A. S., \& Coatsworth J. D. (1998). The development of competence in favorable and unfavorable environments: Lessons from research on successful children. American Psychologist, 53(2), 205-220. https://doi.org/10.1037/0003-066X.53.2.205 
Metin, N., \& Bencik-Kangal, S. (2012). Bilim sanat merkezlerine devam eden 12-14 yaş grubu üstün yetenekli çocukların benlik algılarının incelenmesi [An examination of the self concept of 12 to 14 year-old gifted children enrolled in science and art centers]. Education and Science, 37(163), 3-16. http://egitimvebilim.ted.org.tr/index.php/EB/article/viewFile/24/333

Moon, J. R., Song, J., Huh, J., Kang, I. S., Park, S. W., Chang, S. A., Yang, J. I., \& Jun, T. G. (2017). The relationship between parental rearing behavior, resilience and depressive symptoms in adolescents with congenital heart disease. Frontiers in Cardiovascular Medicine, 4(55), 1-8. https://doi.org/10.3389/fcvm.2017.00055

Morawska, A., \& Sanders, M. R. (2008). Parenting gifted and talented children: What are the key child behaviour and parenting issues? Australian and New Zealand Journal of Psychiatry, 42(9), 819-827. https://doi.org/10.1080/00048670802277271

Neihart, M. (1999). The impact of giftedness on psychological well-being: What does the empirical literature say? Roeper Review, 22(1), 10-17. https://doi.org/10.1080/02783199909553991

Neihart, M. (2002). Risk and resilience in gifted children: A conceptual framework. In M. Neihart, S. M. Reis, N. Robinson, \& S. Moon (Eds.), The social and emotional development of gifted children: What do we know? (pp. 114-119). Prufrock Press.

Neihart, M., \& Yeo, L. S. (2018). Psychological issues unique to the gifted student. In S. I. Pfeiffer (Ed.), APA handbook of giftedness and talent (pp. 497-510). American Psychological Association.

Nunnally, J. C., \& Bernstein, I. R. (1994). Psychometric theory. McGraw-Hill.

Oğurlu, Ü. (2010). Üstün zekâlı ve yeteneklilerde sosyal uyum ve arkadaşlık ilişkileri: Literatür taraması [Social adjustment and friendship relations in gifted and talented: Literature review]. Çukurova Üniversitesi $\begin{array}{llll}\text { Eğitim Fakültesi } & \text { Dergisi, } & \text { 90-99. }\end{array}$ https://app.trdizin.gov.tr/publication/paper/detail/TVRJd05ETXdNQT09

Olgun-Kaval, N. (2014). Üstün yetenekli ve normal çocukların ebeveyn kabul-red, ebeveyn tutumu ve sosyal destek alglları ile yaşadıklarl psikolojik güçlükler arasindaki ilişkinin incelenmesi [Investigation of the relationship between gifted and normal children's perception of parental acceptance-rejection, parental styles, social support and their psychological difficulties] (Tez Numaras1: 378584) [Yüksek lisans tezi, Ege Üniversitesi]. Yükseköğretim Kurulu Ulusal Tez Merkezi.

Önder, A., \& Gülay, H. (2008). İlköğretim 8. sınıf öğrencilerinin psikolojik sağlamlığının çeşitli değişkenler açısından incelenmesi [Resilience of 8 grade students in relation to various variables]. Dokuz Eylül $\begin{array}{llllll}\text { Üniversitesi Buca Ĕgitim } & \text { Fakültesi } & \text { Dergisi, } & 23, & 192-197 .\end{array}$ https://dergipark.org.tr/tr/pub/deubefd/issue/25428/268260

Özbey, F., Ellibeş-Cerrah, H., \& Arpaz-Ünsal, Ş. (2021). Özel yetenekli çocukların kendi arkadaşlık ilişkilerine yönelik görüşleri [The perceptions of the gifted children regarding their friendship relations]. Ankara Üniversitesi Eğitim Bilimleri Fakültesi Özel Eğitim Dergisi, 22(1), 113-145. https://doi.org/10.21565/ozelegitimdergisi.621484

Özdemir, Y. (2012). Ergenlerin öznel iyi oluşlarının özerk, ilişkisel ve özerk-ilişkisel benlik kurguları açısından incelenmesi [Examination of adolescent's subjective well- being in terms of autonomous, relational and autonomous-relational self-construal]. Turkish Psychological Counseling and Guidance Journal, 4(38), 188-198. https://dergipark.org.tr/tr/download/article-file/200052

Peterson, J., Duncan, N., \& Canady, K. (2009). A longitudinal study of negative life events, stress and school

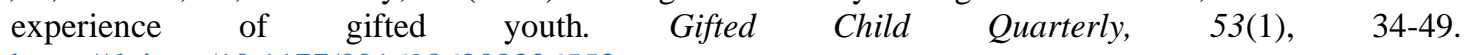
https://doi.org/10.1177/0016986208326553

Pfeiffer, S. I., \& Stocking, V. B. (2000). Vulnerabilities of academically gifted students. Special Services in Schools, 16(1-2), 83-93. https://doi.org/10.1300/J008v16n01_06

Pollet, E., \& Schnell T. (2017). Brilliant: But what for? Meaning and subjective well-being in the lives of intellectually gifted and academically high-achieving adults. Journal Happiness Studies, 18, 1459-1484. https://doi.org/10.1007/s10902-016-9783-4 
Reis, S. M., Robert D. C., \& Hébert, T. P. (2004). Understanding resilience in diverse, talented students in an urban high school. Roeper Review, 27(2), 110-120. https://doi.org/10.1080/02783190509554299

Renati, R., Bonfiglio, N. S., \& Pfeiffer, S. (2017). Challenges raising a gifted child: Stress and resilience factors within the family. Gifted Education International, 33(2), 145-162. https://doi.org/10.1177/0261429416650948

Rimm, S. (2002). Peer pressures and social acceptance of gifted students. In M. Neihart, S. M. Reis, N. M. Robinson, \& S. M. Moon (Eds.), The social and emotional development of gifted children: What do we know? (pp. 13-18). Prufrock Press.

Roedell, W. C. (1984). Vulnerabilities of highly gifted children. Roeper Review, 6(3), 127-130. https://doi.org/10.1080/02783198409552782

Salman-Engin, S., Sümer, N., Sağel, E., \& McHale, J. (2018). Coparenting in the context of "mother-father-infant" and "mother-grandmother-infant" triangular interactions in Turkey. Journal of Child and Family Studies, 27, 3085-3095. https://doi.org/10.1007/s10826-018-1094-4

Saranlı, A. G. (2017). Eş zamanlı olmayan gelişimin üstün yetenekli çocuklardaki görünümü üzerine bir örnek olay çalışması [A case study on the manifestation of asynchronous development in gifted children]. Ankara Üniversitesi Eğitim Bilimleri Fakültesi Özel Eğitim Dergisi, 18(1), 89-108. https://doi.org/10.21565/ozelegitimdergisi.300060

Saranl, A. G., \& Metin, N. (2012). Social-emotional problems observed in gifted children. Journal of Faculty of Educational Sciences, 45(1), 139-163. https://doi.org/10.1501/Egifak_0000001239

Saranl, A. G., \& Metin, E. N. (2014). SENG üstün yetenekliler aile eğitimi modelinin üstün yetenekli çocuklar ve ailelerine etkileri [The effects of the SENG parent education model on parents and gifted children]. $\begin{array}{llll}\text { Eğitim ve Bilim, } & 39(175), & 1-13 .\end{array}$ https://app.trdizin.gov.tr/publication/paper/detail/TWpNMU56azNOdz09

Seligman, M. E. P., \& Csikszentmihalyi, M. (2000). Positive psychology. American Psychologist, 55(1), 5-14. http://dx.doi.org/10.1037/0003-066X.55.1.5

Sternberg, R. J., Grigorenko, E. L., \& Bundy, D. A. (2001). The predictive value of IQ. Merrill-Palmer Quarterly, 47(1), 1-41. http://dx.doi.org/10.1353/mpq.2001.0005

Tabachnick, B. G., \& Fidell, L. S. (2013). Using multivariate statistics (6th ed.). Pearson Education.

Taber, K. S. (2018). The use of Cronbach's Alpha when developing and reporting research instruments in science education. Research in Science Education, 48(1), 1273-1296. https://doi.org/10.1007/s11165-016-9602$\underline{2}$

Tebbs, T. J., \& Subhi-Yamin, T. (2006). The New Millennium in Mind survey: An assessment of professional $\begin{array}{llll}\text { confidence. } \quad \text { Gifted and Talented International, } & \text { 21(2), }\end{array}$ https://doi.org/10.1080/15332276.2006.11673475

Tohum, M. (2018). Özel yeteneklilerin 'mutluluk' kavramına ilişkin metaforik algılarının incelenmesi [Examination of the metaphoric perceptions related to the concept of happiness for the gifted children] (Tez Numarası: 532778) [Yüksek lisans tezi, İstanbul Aydın Üniversitesi]. Yükseköğretim Kurulu Ulusal Tez Merkezi.

Topçu, S. (2015). Üstün ve normal zihin düzeyine sahip öğrencilerde içsel-dlşsal motivasyon ve benlik saygı düzeyi arasindaki ilişki [Relationship between internal-external motivation and self esteem in students with superior and normal intelligence levels] (Tez Numaras1: 396619) [Yüksek lisans tezi, İstanbul Üniversitesi]. Yükseköğretim Kurulu Ulusal Tez Merkezi.

Uçak-Azboy, Z. (2020). Üstün zekâll/yetenekli çocuklarda psikolojik sağlamlık ve sosyal sermaye ilişkisi [Relationship between resilince and social capital in gifted/talentad children] (Tez Numarasi: 608878) [Yüksek lisans tezi, Çağ Üniversitesi]. Yükseköğretim Kurulu Ulusal Tez Merkezi. 
Uysaler, H. (2015). Arkadaşlık becerilerini gelişstirme programının üstün zekâlı öğrencilerin arkadaşlık ilişkilerini etkisi [The effect of friendship skills development program on the friendship relations of gifted students] (Tez Numarası: 399461) [Doktora tezi, İstanbul Üniversitesi]. Yükseköğretim Kurulu Ulusal Tez Merkezi.

Van Griethuijsen, R. A. L. F., Van Eijck, M. W., Haste, H., Brok, P. J., Skinner, N. C., Mansour, N., SavranGencer, A., \& BouJaoude, S. (2014). Global patterns in students' views of science and interest in science. Research in Science Education, 45(4), 581-603. https://doi.org/10.1007/s11165-014-9438-6

Vötter, B. (2019). Crisis of meaning and subjective well-being: The mediating role of resilience and self-control among gifted adults. Behavioral Sciences, 10(1), 15. https://doi.org/10.3390/bs10010015

Yazdani, S., \& Daryei, G. (2016). Parenting styles and psychosocial adjustment of gifted and normal adolescents. Pasific Science Review B: Humanities and Social Sciences, 2(3), 100-105. https://doi.org/10.1016/j.psrb.2016.09.019

Yıldız, S. (2018). Üstün yetenekli çocukların ve akranlarının algıladıkları ebeveyn tutumları, psikososyal sorunlar ve yaşam kalitesi [Parental attitudes, psychosocial problems and life quality of gifted children and their peers] (Tez Numarası: 535748) [Yüksek lisans tezi, Gazi Üniversitesi]. Yükseköğretim Kurulu Ulusal Tez Merkezi.

Yılmaz, A. (2000). Eşler arasındaki uyum ve çocuğun algıladığı anne-baba tutumu ile çocukların, ergenlerin ve gençlerin akademik başarıları ve benlik algıları arasındaki ilişkiler [Relationships between marital adjustment, child perception of parenting style and children, adolescent and young adults academic achievement and self-perceptions] (Tez Numarasi: 98640) [Doktora tezi, Hacettepe Üniversitesi] Yükseköğretim Kurulu Ulusal Tez Merkezi.

Wandansari, Y. (2011). Faktor protektif pada penyesuaian sosial anak berbakat. INSAN Media Psikologi, 13(2), 85-95. https://adoc.pub/faktor-protektif-pada-penyesuaian-sosial-anak-berbakat.html

Wener, R. W. (2016). Evaluating resilience in Syrian and Jordanian youth [Master thesis, Yale School of Public Health]. https://elischolar.library.yale.edu/cgi/viewcontent.cgi?article=1318\&context=ysphtdl

Werner, E. E. (1989). High-risk children in young adulthood: A longitudinal study from birth to 32 years. American Orthopsychiatric Association, 59(1), 72-81. https://doi.org/10.1111/j.1939-0025.1989.tb01636.x

Yürük, A. (2003). İlköğretim çağındaki üstün yetenekli öğrencilerle normal gelişim gösteren öğrencilerin benlik saygılarınin karşllaştırılması [Comparison of self confidences of talented primary school students with students showing normal growth] (Tez Numarası: 122219) [Yüksek lisans tezi, Hacettepe Üniversitesi]. Yükseköğretim Kurulu Ulusal Tez Merkezi.

Zakeri, H., Jowkar, B., \& Razmjoee, M. (2010). Parenting styles and resilience. Procedia Social and Behavioral Sciences, 5, 1067-1070. http://dx.doi.org/10.1016/j.sbspro.2010.07.236

Zhang, L. F., \& Sternberg, R. J. (2000). Are learning approaches and thinking styles related? A study in two $\begin{array}{lllll}\text { Chinese populations. Journal of } & \text { Psychology, } & 134(5), & 469-489 .\end{array}$ https://doi.org/10.1080/00223980009598230

Zhong, X., Wu, D., Nie, X., Xia, J., Li, M., Lei, F., Lim, H. A., Kua, E-H., \& Mahendran, R. (2016). Parenting style, resilience and mental health of community-dwelling elderly adults in China. BMC Geriatrics, 16(135), 1-8. https://doi.org/10.1186/s12877-016-0308-0

Zulfikar, Z., Hidayah, N., Triyono, T., \& Hitipeuw, I. (2020). Development study of Academic Resilience Scale for gifted young scientists education. Journal for the Education of Gifted Young Scientists, 8(1), 342-358. http://dx.doi.org/10.17478/jegys.664116 


\section{Ankara University Faculty of Educational Sciences Journal of Special Education}

2022, 23(2), 271-294
RESEARCH

Recieved Date: 25.05 .20

Accepted Date: 17.06.21

OnlineFirst: 11.07 .21

\title{
The Predictors of Gifted Students' Resilience: Self Esteem, Peer Relationship and Parental Attidutes*
}

\author{
İrem Yörük-Topuz $\mathbb{D}$
}

\author{
Zeynep Cihangir-Çankaya (iD)2
}

\begin{abstract}
Introduction: This study was conducted to examine the role of self-esteem, parental attitudes and peer relationships in the resilience levels of gifted students. The problem statement of this research is "What is the power of self-esteem, parental attitudes and peer relationships in predicting gifted students' psychological resilience?"

Method: Correlational survey method was used in the research. The study group consisted of a total of 219 students (6th, 7th, 8th, 9th grade and high school preparatory class students) attending three separate Science and Art Centers. Data were collected by Adolescent Psychological Resilience Scale, Rosenberg Self-Esteem ScaleShort Form, Parenting Style Scale and Friendship Qualities Scale. Multiple regression analysis was used to analyze the data.

Findings: The results of the study revealed that the acceptance / involvement and psychological autonomy support received from parents, self-esteem and peer relations variables significantly predicted the psychological resilience levels of gifted students, while parents' control / strictness behaviors did not significantly predict. It was seen that acceptance/involvement received from parents was the strongest variable predicting the resilience of gifted students.

Discussion: Findings obtained from the study show that self-esteem, family and friend relationships have an important power in explaining the resilience of gifted students. However, research results revealed that external protective factors such as acceptance/involvement received from parents and peer relationships explain the resilience levels of gifted students more strongly. In addition, it is seen that self-esteem, an internal protectiv factor, significantly predicts the resilience of gifted students.
\end{abstract}

Keywords: Gifted and talented students, resilience, self esteem, parental attidutes, peer relationship.

To cite: Yörük-Topuz, İ., \& Cihangir-Çankaya, Z. (2022). The predictors of gifted students' resilience: Self esteem, peer relationship and parental attitudes. Ankara University Faculty of Educational Sciences Journal of Special Education, 23(2), 271-294. https://doi.org/10.21565/ozelegitimdergisi.742426

${ }^{*}$ This research is the summary of the master's thesis study (2019), which is titled 'Investigation Resilience Levels of Gifted Students According to Self Esteem, Peer Relationship and Parental Attidutes'.

${ }^{1}$ Psychological Counselor, Erdek Karşıyaka Middle School, E-mail: iremyoruk35@gmail.com, https://orcid.org/0000-00033883-4783

${ }^{2}$ Corresponding author: Assoc. Prof., Ege University, E-mail: zeynep.cankaya.cihangir@ege.edu.tr, https://orcid.org/0000$\underline{0001-7120-931 X}$ 


\section{Introduction}

In recent years it is stated that in order to support the positive functioning of people, it is necessary to study the strengths and positive emotions rather than to focus on weaknesses, deficiencies, and pathologies (Seligman \& Csikszentmihalyi, 2000). Positive psychology is concerned with how to build the best and to make the lives of healthy people more fulfilling as well as to repair the disordered and cure diseases (Bişgin, 2013). Resilience determines the difference between individuals who successfully survive the stress, risks, and difficulties encountered in life and those who cannot (Zakeri et al., 2010). The common features in the definitions of resilience are risk factors, protective factors that reduce the negative effect, and adaption (competence) (Fraser et al., 1999; Gizir, 2007; Işık, 2016). The individual can cope with difficulties as long as he/she can balance risks, stressful life events, and protective factors. However, even if the risk factors and stressful life events outweigh the protective factors, an individual with high resilience may have problems (Werner, 1989).

Although low IQ is considered as a risk factor (Dole, 2000), having a high IQ or gift/talent is not always a protective factor. High intelligence (high IQ) which is one of the characteristics of gifted students is seen as a feature of resilient individuals and considered as a protective factor in resilience studies (Fergusson \& Lynskey, 1996; Gizir, 2007; Gürgan, 2006; Karaırmak, 2006; Masten \& Coatsworth, 1998). However, features such as the asecron development of gifted individuals, the expectations of their families and the environment, lack of satisfaction in educational settings put them into disadvantageous positions and besides create risk factors for gifted children (Pfeiffer \& Stocking, 2000). Also gifted students may have personality traits that can make them more vulnerable to social and emotional problems (Pfeiffer \& Stocking, 2000). It is stated that they can experience social-emotional difficulties because they are gifted (Altman, 1983; Buescher, 1985; Freeman, 1983; Gallagher, 1990; Roedell, 1984). Because their asynchronous development may be superior to their peers in some developmental areas, in others at an average level, and in others behind their peers (Saranl1,2017). Therefore, it is thought that being gifted can also be a risk factor. There are two opposing views on the psychological well-being of gifted children, that talent enhances children's resilience and increases vulnerability (Neihart, 1999; Neihart \& Yeo, 2018). It is thought that psychological resilience is the feature that will help gifted children to cope with social-emotional problems such as perfectionism, stress, loneliness, and depression, as stated in the compilation study by Saranlı and Metin (2012). In this study, a gap was tried to be filled by examining the effect of internal and external protective factors in resilience. Gifted children need to have high psychological resilience in order to balance between maintaining relationship with their friends and exerting effort in their field (Zulfikar et al., 2020) it has been emphasized that the characteristics that will protect these children against risks when they become adults are their psychological resilience capacity (Alexopoulou et al., 2019). Reis et al. (2004) revealed that psychological resilience is an important feature that can distinguish between successful and non-successful gifted students. Similarly, the need to improve the academic resilience of especially gifted but low achieving children has been refered (Zulfikar et al., 2020).

Resilience studies with children and adolescents in the literature were examined. Accordingly, it is seen that the number of studies on disadvantaged individuals (Bumpus, 2014; Eminağaoğlu, 2006; Er, 2009; Kidd \& Shahar, 2008) is higher than studies conducted with gifted individuals (Chen vd., 2017; King, 2009; Kline \& Short, 1991). In our country, the variables of self-esteem (Albayrak-Dengiz, 2014; Altun \& Yazıcı, 2012; BüyüktaşkapuSoydan \& Kabar, 2020; Olgun-Kaval, 2014), parental attitudes (Afat, 2013), peer relations (Erol, 2015; Oğurlu, 2010; Özbey et al., 2020), emotional intelligence (Koçak \& İçmenoğlu, 2012), communication skills (Koç, 2015), and social emotional problems (Saranlı \& Metin, 2012) of gifted students were examined in researchs. However, in Turkey, there is one research (Uçak-Azboy, 2020) on the resilience of gifted children. Resilience was examined only in the families of gifted children (Kahvecioğlu, 2016). Therefore, in this research, it is thought that identifying the risk conditions and examining protective factors for gifted students will contribute to the literature.

The aim of this study is to investigate the role of self-esteem, parental attitudes, and peer relationships in predicting the resilience of gifted students. Lee and colleagues (2013) stated that increasing protective factors (eg self-efficacy, positive affect, and self-esteem) to increase resilience is more effective than reducing risk factors (eg depression and anxiety). Therefore, this study focused on self-esteem, peer relationships and parental attitudes as protective factors. The problem statement of this research is "What is the power of self-esteem, parental attitudes, and peer relationships in predicting gifted students' psychological resilience?"

It is important to examine the resilience of gifted individuals in terms of their potential to play an active role in the future of society. Therefore, it is aimed to reveal the effect of protective factors in increasing the resilience of these individuals by ignoring the risks of being gifted. Also focusing on protective factors may provide 
insight into how to discover or improve resilience in gifted children. Especially in Turkey, it is thought that counselors and teachers working with gifted students may provide important information to the parents of gifted studentson how to increase the psychological resilience of specially gifted children by revealing the effect of protective factors that are effective in increasing the psychological resilience of gifted students. Also, the protective aspect of resilience is considered as an important concept for preventive guidance services. In a broad sense, this research is thought to contribute to preventive mental health services.

\section{Method}

\section{Research Model}

This research is a descriptive research based on a relational screening model to determine the predictive power of self-esteem, parental attitudes, and peer relationships in gifted students' psychological resilience. Descriptive model that is used commonly aims to describe the situation. Screening models is research approach that aims to describe the situation as it is. The relational screening model as a model which aims to determine whether there is a change of more than one variable and the degree of this change (Karasar, 2014).

\section{Participants}

The participants consisted of 219 preparatory and $6^{\text {th }}, 7^{\text {th }}, 8^{\text {th }}$ and $9^{\text {th }}$ grade students attending to three different Science and Art Centers in a province in Turkey in the West in 2018-2019 academic year. Convenience sampling method was used in the study. This method is preferred when it is difficult (sometimes impossible) to use another sampling method (Fraenkel \& Wallen, 2009). The convenience sampling method was used in the research because of the difficulty in obtaining research permission from relevant institutions and working with a special group.

\section{Data Collection Tools}

In the study, Adolescent Psychological Resilience Scale was used to measure resilience. The scale, developed by Bulut and collegues (2013), consists of 29 items and 6 dimensions including family support, confidant-friend support, school support, adjustment, sense of struggle, and empathy. Rosenberg Self-Esteem Scale Short Form was used to measure self-esteem. Rosenberg Self-Esteem Scale, developed by Rosenberg, consists of 63 items and 12 sub-categories. In this study, the self-esteem subcategory consisting of 10 items was used. Reliability and validity studies in Turkey of Rosenberg Self-Esteem Scale were done by Çuhadaroğlu (1986). Parental Style Scale was used to measure parental attitudes. The scale developed by Lamborn and colleagues (1991) consists of 26 items and 3 factors including acceptance-involvement, strictness/control, and psychological autonomy (Y1lmaz, 2000). Turkish adaptation study of Parenting Style Scale was done by Y1lmaz (2000). Friendship Qualities Scale was used to measure peer relationships. The scale was developed by Bukowski and collegues (1994), and adaptation studies were done by Erkan-Atik and colleagues (2014). It consists of 22 items from the scale and 5 sub-dimensions, companionship, conflict, help, security, and closeness.

\section{Data Collection and Data Analysis}

In the process of data collection, first, the necessary approval was obtained from the Scientific Research and Publication Ethics Committee of the number 85553214-050.06.04 dated 01/11/2018. Afterward, necessary permissions were obtained from Balıkesir Provincial Directorate of National Education. The research data were collected in a period of approximately 2 months, the 2018-2019 academic year.

The purpose and importance of the research were explained to the school management and counselors in the institutions where the application would be performed, and the date and time were planned. Data collection tools were applied by one of the researchers, counselors, and teachers. Before the application, students were given general information about the research. It was emphasized that the answers would be kept secret, they would not be shared with their teachers and parents. The prepared scale battery was applied in approximately 20 minutes. In this study, the stepwise multiple regression analysis method was used to determine the predictive power of selfesteem, parental attitudes, and peer relationships in the resilience of gifted students.

\section{Findings}

According to the results, the correlation between the resilience of gifted students and the acceptance/involvement and psychological autonomy dimension of peer attitudes were positive and a significant relationship was found. There was a significant negative correlation between the resilience and self-esteem. There 
was no significant relationship between resilience and strictness /supervision, which is one of the sub-dimensions of the parental attitude scale. Therefore, this dimension was not included in the regression analysis.

Multiple regression analysis was conducted in four stages. In the first stage, the parental attitudes acceptance/involvement dimension was analyzed. The dimension of acceptance/involvement alone explained $31.1 \%$ of the total variance. In the second stage, peer relationships were analyzed. Together with this variable, the total variance of resilience increased to $41.4 \%$. Peer relationships increased total variance to $10.3 \%$. In the third stage, the self-esteem was included in the multivariate analysis. The additional contribution of self-esteem variable was $6.9 \%$ and the total variance of resilience increased to $48.3 \%$. In the fourth stage, psychological autonomy dimension was included in the analysis. The additional contribution of this variable was $1.6 \%$ and the total variance of resilience was increased to $49.9 \%$. As the result of multiple regression analysis, acceptance/involvement, peer relationships, self-esteem, and psychological autonomy were significant predictors of resilience and explained the $49.9 \%$ of total variance.

As a result, it was concluded that while parental attitudes, acceptance/involvement dimension, peer relationships, self-esteem, and parental attitudes were significant predictors of the resilience of gifted students, parental attitudes strictness/ supervision dimension was not a predictor of the resilience of gifted students. According to this study, it was determined that resilience levels increased as the levels of acceptance/involvement and psychological autonomy, self-esteem, and peer relations increased from the parental attitudes sub-dimensions of gifted students.

\section{Discussion}

The aim of the study was to examine the predictive power of self-esteem, parental attitudes, and peer relationships on the resilience levels of gifted students. In the study, it was found that the self-esteem, peer relationships, parental acceptance/involvement, and psychological autonomy scores of the gifted students explained $50 \%$ of the total variance in the resilience scores, and the strictness/supervision dimension did not significantly predict the level of resilience. The disclosure rate obtained is considered to be a very high level (Cohen, 1988). These findings show that self-esteem, family, and friend relationships have an important role in explaining the resilience of gifted children.

The findings of the study regarding parents attitudes show that acceptance/involvement and autonomy support from parents are significant predictors of resilience but control/strictnessis not a significant predictor. It was seen that acceptance/involvement from parents was the strongest variable predicting the resilience and explained $31 \%$ of the total variance alone. In this direction, it can be said that the warm, close, accepting relationship with their families is an important protective factor in overcoming the possible problems faced by gifted children. Parents with this attitude can contribute to the increase of their psychological resilience by being more sensitive, understanding, helpful to their children's needs and asynchronous development, and by establishing a positive and close relationship with them. In the related literature, there are studies conducted with different populations (university students, adults aged 60-91, adolescents aged 13-18) that support these results (Moon et al., 2017; Zakeri et al., 2010; Zhong et al., 2016). In studies conducted with gifted children, it was observed that parental attitudes were effective on psychosocial adjustment, behavioral and emotional difficulties of talented individuals (Dwairy, 2004; Morawska \& Sanders, 2008).

The results of the research show that the psychological autonomy that gifted children get from their parents is effective on their resilience levels. It is considered important that the effect size of psychological autonomy taken from parents on resilience is lower than acceptance and involvement. This result is consistent with a few studies with different age groups in our country within the scope of the need for autonomy (CihangirÇankaya \& Denizli 2020; Kandemirci, 2018) and autonomous self-construct (Özdemir, 2012). In studies conducted with children and young people living in Turkey indicated the proximity and the need to be associated, has been demonstrated to have a higher priority than autonomy needs. It is important that parents' strictness /supervision behavior does not have an impact on children's resilience levels. There are studies consistent with this finding in the relevant literature (Zakeri et al., 2010). It is thought that there may be cultural reasons for the different effects of parental attitudes on children's resilience levels. Turkish family culture from the geographical location of Turkey bears traces of both east and west cultures. In more traditional families, the emphasis and mutual commitment to the family point to the socialist structure of Turkish culture (Salman-Engin et al., 2018). Accordingly, as a result of the research, the acceptance/involvement received from parents was the strongest variable that predicted the psychological resilience of gifted students and alone explained $31 \%$ of the total variance. This situation explains that the dimension of psychological autonomy from parents' attitudes has low predictive 
power. Because it is stated that collectivism is positively associated with the need for commitment and negatively with the need for autonomy (Hui \& Villareas, 1989). Strictness/control and psychological autonomy dimensions are interconnected among parents' attitudes. Because there is talk of choice in autonomous behaviors and compliance and submission in behaviors based on control (Deci et al., 1991). An environment providing autonomy support is needed to meet the autonomy needs of children. Social environment supporting autonomy; it provides the person the opportunity to choose, allowing the person to act with his autonomous will, making it easier to absorb values and act with intrinsic motivation (Kındap, 2011).

Findings from the research show that peer relationships positively predict the level of resilience of gifted students. According to this, it can be said that the students with high peer relationships scores have high resilience. There are findings in the literature that friendship relationships are predictors of academic resilience (Gizir, 2004) and resilience (Gökden-Kaya, 2007) and that individuals with high resilience level have high self-perception competence in friendship relationships (Jew et al., 1999). Also, research results show that peer acceptance can help children at risk as a strong protective factor (Criss et al., 2002). While there are research results in the literature that indicate that peer relationships have a positive effect on the development of academic and creative abilities (Lee, 2002); it is also stated that peer relationships can be challenging experiences for gifted students (Peterson et al., 2009). Accordingly, it is thought that peer relationships are critical as a protective factor in terms of coping with individual and family difficulties due to their special talent, experiencing peer acceptance with their characteristics differentiating from their peers and providing peer support. At the same time, it is thought that having a healthy peer relationship may cause the gifted individual to reduce the tendency to hide their talents by providing peer admissions, and thus, it can increase the level of resilience by contributing positively to talent development. In short, the effect of peer relationships on the individual's level of resilience as a protective factor directly; it is thought to be indirectly by contributing to talent development.

In the study, it was found that self-esteem predicted the level of resilience in a negative way. In this context, it can be said that the resilience of gifted students with high self-esteem is also high. Although research results are showing that self-esteem is not a meaningful predictor of resilience (Gökden-Kaya, 2007), and there is a significant negative relationship between self-esteem and resilience (Bumpus, 2014), many studies have shown that resilient individuals have high self-esteem (Benetti \& Kambouropoulos, 2006; Buckner et al., 2003; Dumont \& Provost, 1999; Fergusson \& Lynskey, 1996; Masten \& Coatsworth, 1998) and self-esteem is the predictor of resilience (Balgiu, 2017; Bayköse et al., 2017; Eryılmaz, 2012). Based on this finding, it can be said that gifted students to have high self-esteem contributes to cope with the difficulties arising from their being of special talent. The high self-esteem of gifted students also enables them to believe in their talents, to feel confident in their progress in line with their talents, and to show their talents creatively.

The research has some limitations. One of them is that the sample of the research consists of students attending Science and Art Centers in a city. The research is a correlational study. For this reason, the findings obtained as a result of the analysis were evaluated within the framework of relationality, not causality. This can be considered as another limitation of the research.

The findings of the research revealed that the psychological resilience levels of gifted students were explained more strongly by external protective factors (acceptance/involvement received from parents and peer relations) and self-esteem, an internal protective factor, significantly predicted. The findings of the study provided additional evidence of the role of closeness and acceptance-based family relationships. Since this study is one of the first studies to investigate resilience in gifted students in Turkey, it will be possible to examine the resilience of gifted children in depth with new research. In line with the findings of the research, it may be recommended to organize psychoeducational studies and seminars for parents of gifted students, aimed at increasing acceptance, interest, and warmth in the family atmosphere. Studies can be conducted to raise self-esteem with gifted children. In line with the finding that the research has a positive meaningful relationship between peer relationships and resilience of gifted students, group studies can be planned to develop social skills and peer relationships for gifted students who have difficulties in their relationships with their peers or social skills.

\section{Author's Contributions}

The research is a summary of the master's thesis. The research topic and research method were determined by both authors. Data collection and data analysis studies were carried out by the first author. The research report was written by both authors, mainly the responsible author. 